\begin{tabular}{|l|l|}
\hline $\begin{array}{l}\text { The value of redistribution: natural resources and the formation of human capital } \\
\text { under weak institutions }\end{array}$ & Titulo \\
\hline $\begin{array}{l}\text { Monge Agüero, Jorge - Autor/a; Balcázar, Carlos Felipe - Autor/a; Maldonado, } \\
\text { Stanislao - Autor/a; Nopo, Hugo - Autor/a; }\end{array}$ & Autor(es) \\
\hline Lima & Lugar \\
\hline Grupo de Análisis para el Desarrollo & Editorial/Editor \\
\hline 2017 & Fecha \\
\hline Avances de investigación no. 28 & Colección \\
\hline $\begin{array}{l}\text { Impuestos; Redistribución del ingreso; Capital humano; Minería; Recursos naturales; } \\
\text { Educación; Rendimiento escolar; Perú; }\end{array}$ & Temas \\
\hline Doc. de trabajo / Informes & Tipo de documento \\
\hline "http://biblioteca.clacso.edu.ar/Peru/grade/20170803053511/Al28.pdf" & URL \\
\hline $\begin{array}{l}\text { Reconocimiento-Sin Obras Derivadas CC BY-ND } \\
\text { http://creativecommons.org/licenses/by-nc-nd/2.0/deed.es }\end{array}$ & Licencia \\
\hline
\end{tabular}

Segui buscando en la Red de Bibliotecas Virtuales de CLACSO http://biblioteca.clacso.edu.ar

Consejo Latinoamericano de Ciencias Sociales (CLACSO)

Conselho Latino-americano de Ciências Sociais (CLACSO)

Latin American Council of Social Sciences (CLACSO)

www.clacso.edu.ar

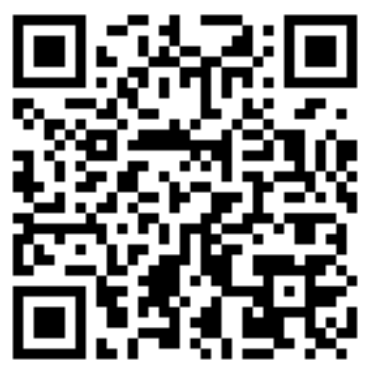




\section{Avances de Investigación}

Recursos naturales, industrias extractivas y conflictos sociales
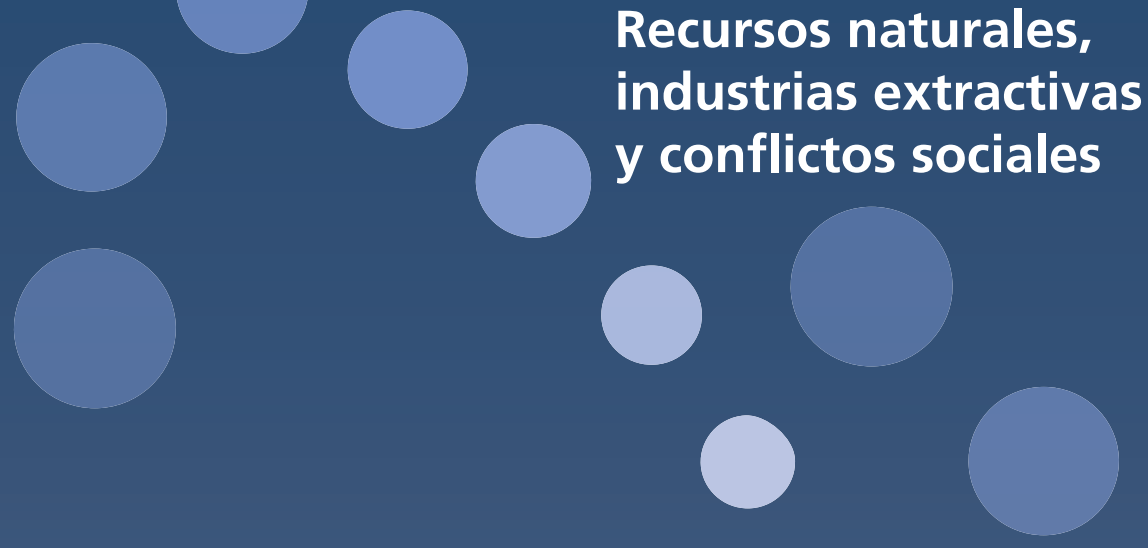

The Value of Redistribution:

Natural Resources and the Formation of

Human Capital under Weak Institutions

Jorge M. Agüero

Carlos Felipe Balcázar

Stanislao Maldonado

Hugo Ñopo
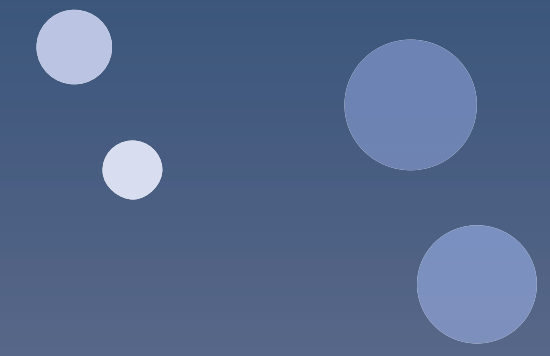

The Value of Redistribution:

Natural Resources and the Formation of Human Capital under Weak Institutions 



\title{
1VGRADE
}

Grupo de Análisis para el Desarrollo

Avances de Investigación 28

\section{The Value of Redistribution: \\ Natural Resources and the Formation of Human Capital under Weak Institutions}

\author{
Jorge M. Agüero, Carlos Felipe Balcázar, \\ Stanislao Maldonado and Hugo Nopo ${ }^{1}$
}

1 Agüero (Corresponding author: jorge.aguero@uconn.edu): Department of Economics and El Instituto, University of Connecticut, 65 Fairfield Way, Storrs, Connecticut. United States of America. Balcázar: Poverty Global Practice, the World Bank Group, 1818 H St. NW, Washington D.C. United States of America. Maldonado: Department of Economics, Universidad del Rosario, Calle 12C No. 6-25, Bogotá, Colombia. Noopo: Grupo de Análisis para el Desarrollo, Av. Almirante Grau 915, Lima, Peru. Juliana Aragón provided excellent research assistance. 
GRADE's research progress papers have the purpose of disseminating the preliminary results of research conducted by our researchers. In accordance with the objectives of the institution, their purpose is to perform rigorous academic research with a high degree of objectivity, to stimulate and enrich the debate, design and implementation of public policies. The opinions and recommendations expressed in these documents are those of their respective authors; they do not necessarily represent the opinions of their affiliated institutions. The authors declare to have no conflict of interest related to the current study's execution, its results, or their interpretation. The publication, but not the research on which it was based, is funded by the International Development Research Centre, Canada, through the Think Tank Initiative.

Lima, August 2017

GRADE, Group for the Analysis of Development

Av. Almirante Grau 915, Barranco, Lima, Peru

Phone: (51-1) 247-9988

Fax: (51-1) 247-1854

www.grade.org.pe

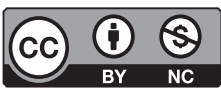

The work is licensed under a Creative Commons Attribution-NonCommercial 4.0 International

Research director: Santiago Cueto

Edition assistance: Diana Balcázar T.

Cover design: Elena González

Design of layout: Amaurí Valls M.

Print: Impresiones y Ediciones Arteta E.I.R.L

Cajamarca 239 C, Barranco, Lima, Perú. Phone: (51-1) 247-4305 / 265-5146 
Index

$\begin{array}{ll}\text { Abstract } & 7\end{array}$

Introduction 9

1. Local transfers in Peru: the case of the canon minero 15

2. Data and descriptive statistics 19

3. Identification strategy 23

4. Results 27

4.1. Effect of mining production 27

4.2. Effect of canon transfers 28

4.3. Robustness checks 29

4.4. Heterogeneous effects 32

4.5. Mechanisms 33

5. Conclusions 39

References $\quad 43$

$\begin{array}{ll}\text { Appendix } & 49\end{array}$ 

We exploit time and spatial variation generated by the commodities boom to measure the effect of natural resources on human capital formation in Peru, a country with low governance indicators. Combining test scores from over two million students and district-level administrative data on mining production and the redistribution of mining taxes to local governments, we find no effect from production. However, redistribution of mining taxes increases math test scores by 0.23 standard deviations. We identify the improvements in the quality of teachers and in school infrastructure, together with increases in adult employment and health outcomes of adults and children, as key mechanisms from the redistribution. Policy implications for the avoidance of the natural resource curse are discussed.

JEL Codes: H7, H23, I25, O15, Q32

Key words: Resource booms, academic achievement, intergovernmental transfers 

A long-standing question in the economics literature explores whether natural resource abundance is a curse or a blessing. The recent commodities boom has brought back this discussion. While the impact of such boom on aggregate economic growth has been explored elsewhere, ${ }^{2}$ the study of the linkages between the abundance of natural resources and human capital formation still requires deeper analysis. For instance, cross-country correlations indicate a negative relationship, suggesting that natural capital crowds out human capital (Gylfason, 2001; Birdsall et al., 2001). ${ }^{3}$ Indeed, as shown in Figure 1, there is a strong negative association between a country's reliance on natural resources and its performance on international standardized tests.

Moreover, despite the natural resource windfall revenues, it remains an open question whether the provision of additional resources to public schools would improve students' learning outcomes (e.g., Hanushek, 1996; Glewwe and Kremer, 2006; Glewwe and Muralidharan, 2016). For instance, as seen in Figure 2, a cross-country scatter plot shows a positive association between tests scores and school resources per student. Nevertheless, it is difficult to consider all these correlations as causal due to the possible presence of unobserved factors across countries.

2 See Aragon et al. (2015), Ross (2014), van der Ploeg (2011), Deacon (2011), Rosser (2006) and Stevens (2003), for comprehensive literature reviews.

3 There is also evidence that good political institutions can ameliorate this outcome (Kronenberg, 2004; Gylfason and Zoega, 2006) 
In this regard, the within-country and micro evidence exploits a single-commodity boom, such as coca in Colombia (Angrist and Kugler, 2008) and oil in Brazil (Caselli and Michaels, 2013), and documents some positive but modest impacts of natural resource abundance on school attendance and attainment, as well as literacy rates. While important, this advancement remains incomplete, given the increasing emphasis on learning outcomes-as the quality of education in developing countries is poor (Hanushek and Woessmann, 2010; Kremer et al, 2013). Furthermore, differences in the quality of education appear to be more important than access to education in explaining the economic performance of countries over the past fifty years (Hanushek and Woessmann, 2012). Thus, a pending question centers on whether the abundance of natural resources affects human capital accumulation beyond traditional measures and more towards the indicators used in Figures 1 and 2.

We address this gap by analyzing the impact of natural resource abundance on students' math and reading skills in Peru, a country that consistently underperforms in the World Bank's governance measures relative to their geographical and income-level counterparts (Kaufmann et al, 2011). The country offers a unique opportunity to evaluate this question for several reasons. First, Peru's poor results in international achievement tests (see figures above), ${ }^{4}$ played an important role in the creation of a national standardized test: the Evaluación Censal de Estudiantes, that since 2007 evaluates yearly the math and reading learning of second graders nationwide. Hence, math and

4 The country is consistently one of the worst performing nations in the Programme for International Student Assessment (PISA) that includes OECD and developing countries. Peru is also the second from the bottom among countries in the Latin American Laboratory for Assessment of the Quality of Education, performing only better than the Dominican Republic. 
reading test scores serve as our proxy for human capital accumulation and allow us to focus on quality measures rather than access.

Second, during the 2000s, Peru benefited from the commodities boom and during the period of our analysis (2007-2012) the country exported over 127.9 billion US dollars in minerals (excluding oil and gas, which are of low relevance). Today, the sector accounts for nearly two-thirds of the value of country's exports ${ }^{5}$ However, the country does not rely on just one mineral. Peru is one of the world top producers of silver, tin, zinc, copper and gold (USGS, 2015). This variety allows us to exploit time and spatial variation in the value of mining production observed in this period. While most mineral prices increased drastically, a few of them plummeted (see Appendix Figure A1). For instance, localities producing lead and iron observed more than a threefold increase in the value of their exports compared to those producing silver and zinc, where exports reduced by half over same period. This multiplicity of commodities in one country permits us to avoid the limitation on the external validity faced by previous studies that focused on a single commodity.

Third, we are able to match a unique administrative dataset collecting the value of mineral production at the district level with close to 2.1 million student records obtained from the national standardized test mentioned previously.

Furthermore, mining revenues constitute around half of the taxes collected by Peru's central government and these revenues have been partially redistributed to local governments. Indeed, the Canon Minero Law (from here on canon), introduced in 2001, states that 50

5 See Appendix Figure A1 for the evolution of mining exports and prices of the main commodities. Note also that Peru has a long history of mining production that precedes colonial times (Dell, 2010). Since colonization, mining production is almost exclusively sent overseas. 
percent of the income tax paid by mining companies to the central government must be redistributed to the regional and local governments located in the areas where minerals are extracted. This legal framework also establishes a redistribution rule that grants transfers to non-producing districts located in the same region of the producing districts. During the period of analysis, the sum of canon transfers was 8.9 billion US\$. In 2012 alone, the central government transferred US $\$ 1.9$ billion as canon; six times the budget allocated to the country's antipoverty conditional cash transfer program (Juntos) and 1.8 times the entire budget of the Ministry of Social Development, which is in charge of all welfare programs. There is also an important variation across space and time. Canon transfers differ significantly even among the top recipients over our period of analysis. ${ }^{6}$ Thus, the Peruvian case allows us to distinguish the impact on learning outcomes of mining production from redistribution policies as measured by canon transfers to local governments.

We exploit the spatial and time variation in the value of mining production to estimate its impact on math and reading test scores. Our difference-in-differences approach reveals a null impact of (the value) of production on test scores, which is robust to several specifications. However, using the additional space and time variation that arises from the redistribution of the mining taxes to local governments, we find that canon transfers have a positive and statistically significant effect on math test scores. We find smaller (and sometimes negative) effects for reading, but they are not statistically significant. These findings remain unchanged when considering several robustness tests, including controls for the value of mining production. Furthermore, two placebo tests further validate our approach: a falsification exercise where we

6 See Appendix Figure A2 for an example of this variation. 
incorrectly assign canon transfers of one district to a randomly selected district in the country, as well as a placebo test limiting the sample to private schools. As expected, both tests show no impact on students' academic achievement, reinforcing the validity of our approach.

Following the political economy literature (e.g., Caselli 2015), we test for the presence of non-monotonic effects of canon transfers. Resource booms could affect the behavior of the local incumbent in a non-linear fashion. Political competition increases as natural resource rents increase and this competition works as a discipline device, creating incentives for investments in public goods provision such as human capital. However, when rents are too high, incumbents have a significant amount of fiscal resources, which allows them to influence electoral outcomes by buying-off citizens' electoral support and reducing competition. Incumbents will have fewer incentives to invest in human capital, for example, since their ability to maintain power is less likely to be challenged.

We find evidence in favor of non-monotonic effects. For the average district receiving a positive transfer, our estimates suggest an increase in math test scores of around 0.23 standard deviations. These effects are larger than the majority of interventions using randomized controlled trials considered in Kremer et al. (2013).

We use additional administrative data, as well as household surveys, to explore some of the possible mechanisms behind our findings. For instance, we show that year-to-year variation in canon transfers is associated with higher expenditure on education at the local government. We complement this with an analysis at the school level, where we find that canon transfers lead to an increase in the quality of teachers and positive investments in school infrastructure (e.g., electricity and sanitation). On the other hand, we do not observe changes in school enrollment, ruling out the possibility that the impact of canon 
transfers on test scores is driven by population effects (i.e., areas with larger windfalls could attract families with children).

Our findings are in line with recent papers exploring the effects of resource windfalls on the behavior of the local government. ${ }^{7}$ For example, Caselli and Michaels (2013) show that oil-rich municipalities in Brazil increase their spending on public goods, but they find mixed results on welfare-relevant outcomes such as household income. Rather, the authors argue that municipal officials used public funds for patronage, rent sharing and possible embezzlement.

Unlike Brazil, canon transfers seem to be less likely to generate malfeasance. Ardanaz and Maldonado (2016) show that districts benefiting from canon transfers in Peru were more efficient in their use of the fiscal windfalls. Furthermore, Loayza and Rigolini (2016) and Zambrano et al. (2014) show that areas benefiting from Peru's mining boom and canon transfers saw significant reductions in their poverty levels. While we cannot properly test it with our framework, it is possible that strict regulations limiting the use of canon resources explain the differences with Caselli and Michael's findings.

The rest of the paper proceeds as follows. In Section 2 we briefly describe the institutional setting of the Peruvian Canon law. In sections 3 and 4, respectively, we present the data sources and the identification strategy. In Section 5 we present our results, including our robustness checks. In Section 6 we summarize our findings.

7 They are also related to a vast literature evaluating the effect of school resources on student performance (e.g., Hanushek, 2006). 


\section{LOCAL TRANSFERS IN PERU: THE CASE OF THE}

CANON MINERO

Several countries have implemented mechanisms that share the taxes and royalties paid by extractive companies with subnational governments. This has been associated with an important expansion of fiscal resources in resource-rich countries, creating opportunities to improve the living conditions of citizens (Brosio and Jimenez, 2012). In the case of Peru, the Law 27506 or Ley del Canon (Canon Law), approved in 2001 , states that the 50 percent of the income tax paid by mining companies should be allocated to the regional and local governments located in the areas where minerals are extracted.

The Canon Law was not related to the commodity boom-increases in mineral prices would take place later in the decade-but rather was implemented as part of the country's decentralization process during the final days of the transitional government. ${ }^{8}$ After several amendments to the original law, ${ }^{9}$ it was established in 2004

8 This law has as a historical antecedent: the Oil Canon, which was established in 1976 during the military government through Decree-Law 21678 after the discovery of oilfields in the Peruvian Amazon. It was later modified in 1992 to include mining activities and stated that 20 percent of the income tax should be allocated to the areas in which the profits were generated. The Canon Law explored in our paper was established by the government of President Valentín Paniagua, who came to power after Alberto Fujimori resigned from the presidency in September of 2000.

9 The original law of 2001 established that 20 percent of the transfers should be assigned to the municipalities of the province where the mineral is extracted, 60 percent to the other provinces in the region and the remaining 20 percent to the regional government. This was changed in 2003 (Law 28077) and again in 2004 (Law 28322) where the distribution applied during our period of analysis was established. 
that canon should be distributed according to the following rule: 10 percent to the municipality of the district where the resources are obtained, 25 percent to the municipalities located in the province where the producing district is located, 40 percent to the municipalities located in the region where the resource is exploited and 25 percent to the regional government in which the producing district is located. ${ }^{10}$

From a fiscal perspective, local governments in Peru play a very marginal role; the central government collects $97 \%$ of taxes (Polastri and Rojas, 2007). Local governments' ability to establish taxes or marginal rates is very limited. Property taxes (vehicles, real estate and real estate transfer) are the main source of local tax revenues for Peruvian municipalities (90\% in 2007), while production and consumption taxes play a small role, representing at most $13 \%$ of local governments' current incomes (Calvo-Gonzalez et al., 2010). Consequently, local governments are highly dependent on central government transfers, representing three-fourths of the local government budget (Canavire-Bacarreza et al., 2012).

Around one-third of these transfers are universally distributed among local governments through the "Fondo de Compensación Municipal" (Municipal Compensation Fund); the rest are allocated as targeted transfers. From these targeted transfers, canon (which may come from mining, oil, hydropower, forest and gas) represents a $91 \%$ of the total targeted transfers, being the mining canon the most important one $(72 \%$ of all canon transfers, representing $29 \%$ of local governments' budgets). In some mineral-producer districts, canon can accounts for as much as $70 \%$ of municipal budgets (CanavireBacarreza et al., 2012).

10 Peru is divided into 24 political regions, which in turn are divided into 196 provinces and into over 1,867 districts or municipalities. Regions and provinces are equivalent to states and counties in the US, respectively. 
By law, mining canon transfers can be used only for investment. This means that any project to be financed with canon funds has to follow the rules of the Public Investment National System (SNIP, for its acronym in Spanish) and obtain the approval of the Ministry of Economics and Finance. The law also prohibits recurring expenses, such as payroll within the local government. These restrictions limit the capacity of local governments to allocate canon funds to rent-sharing and embezzlement in contrast to the of Brazil experience reported by Caselli and Michaels (2013). ${ }^{11}$

11 This of course does no eliminate attempts to circumvent these restrictions. See ArellanoYanguas (2011) and Maldonado (2015) for more details. 



\section{DATA AND DESCRIPTIVE STATISTICS}

This paper combines many large administrative data sources and several household level surveys to estimate the effect of mining production and canon transfers on test scores, and to identify some of the important mechanisms that could lie behind any significant relation. The first dataset is the Evaluacion Censal de Estudiantes (or ECE). This a national standardized test applied yearly since 2007 to all second graders in Peru in public and private schools.

Administered by the Ministry of Education, the ECE collects information about the students' performance in math and reading (with possible scores ranging between 0 and 800 in each subject) plus a small set of students' and schools' characteristics (e.g., gender, mother tongue and type of school). These test scores are our main outcome variable.

Combining the tests scores from the ECE 2007 to 2012, our final sample contains over 2 million student records nationwide. Our sample includes all rural areas. We also include urban areas, except for the capital cities in each of the 24 regions. The exclusion of these largest cities reflects the different social dynamics triggered by mining in these areas compared to rural and smaller cities (Zegarra et al., 2006; Arellano-Yanguas, 2008).

Our second data source, the Censo Escolar (CE), allows us to collect yearly information about schools in terms of infrastructure, personnel and other administrative data. These include the share of 
the teacher body with long-term contracts, access to electricity, water and sanitation, among others. As explained in the next section, we use some of these variables as additional controls (e.g., length of the school day, school administration, and percentage of girls enrolled) while others allow us to explore possible mechanisms (e.g., infrastructure and school personnel).

We merge these datasets with yearly district-level data of mining production and canon transfers. We obtain data on the value of mining production from the annual reports of the Ministry of Energy and Mining. We convert the reported volumes of copper, tin, iron, zinc, molybdenum, silver, gold, tungsten and cadmium, at the district level, into U.S. dollars using current international prices of the corresponding minerals. Canon transfers are the monetary amounts that each district receives annually from the central government. The Ministry of Finance compiles, computes, and reports these figures based on the amount of mining production in the districts themselves. This ministry is also the source of expenditures by local governments on education (and culture) by year. We also convert government transfers into U.S. dollars using nominal exchange rates. We set all monetary values to 2010 prices using the US consumer price index, and express them in thousands of dollars per capita. ${ }^{12}$

Our fifth and final dataset allows us to explore other possible mechanisms, but at the household level. We use several years of the Encuesta Nacional de Hogares (EnAHO), a nationally representative household survey conducted by the Peruvian National Bureau of Statistics (INEI, for its acronym in Spanish) aimed at measuring living standards. ENAHO allows us to estimate the effect of mining production

12 To obtain per-capita values, we divide the values of canon transfers and production by population size estimates at the district level obtained from the Peruvian National Bureau of Statistics (INEI). 
and mining canon transfers on health outcomes of children as well as adults' unemployment status.

Table 1 presents summary statistics for inputs and outputs. To facilitate the presentation we partition the sample into three groups: producing districts, non-producing districts but located in producing provinces, and non-producing districts in non-producing provinces. This classification follows the division created by the Canon Law. The table shows that districts in producing provinces, columns 1 and 2, present higher scores in math and reading on average than other districts, as well as a higher proportion of schools with access to basic services and with better teacher-related outcomes. It also shows that non-producing districts in producing provinces show better outcomes than their counterparts, with mining activities, despite canon transfers are higher for the latter, suggesting the possible presence of non-linear effects. 



\section{IDENTIFICATION STRATEGY}

We exploit variation across districts and time in the value of the mining activity and canon transfers. Our main specification is given by:

$$
y_{i s d t}=\alpha+g\left(m_{d t}\right)+f\left(c_{d t}\right)+\delta_{1} X_{i s d t}+\delta_{2} S_{s d t}+\gamma_{d}+\theta_{t}+\varepsilon_{i s d t}
$$

where $y_{i d t}$ is the test score for the student $i$, enrolled in school $s$, located in district $d$ observed in year $t ; m_{d t}$ is the value of mining production in district $d$ in year $t$ and $c_{d t}$ is the amount of canon transferred to district $d$ in year $t$, both monetary measures are expressed in thousands of US dollars per-capita at constant prices of 2010. $X$ is a vector of socio-demographic characteristics of the student including gender and mother tongue; $S$ is a vector of schools' characteristics varying by time and space. These characteristics include: length of the school day (full-day, half-day morning or half-day afternoon); school administration type (public/private), school type (one-teacher school/full grade) and percentage of girls enrolled in the school. $\gamma_{d}$ and $\theta_{t}$ denote district and year fixed effects respectively. $\varepsilon_{i s d t}$ is an idiosyncratic error term. Standard errors are robust to unknown forms of heteroskedasticity and clustered at the district level (over 1,800 in our sample).

Canon transfers depend on the value of taxes paid by mining companies - which in turn depend not only on the value of production (determined by international prices) and the mineral produced in the locality- but also on the rules of the transfers discussed in Section 2. 
Thus, our goal is to estimate whether, conditional on the value of mining production, year-to-year variation in the amount of canon transfers received by the same district correlates with students' test scores.

As discussed in the introduction, models about the political economy of natural resources predict non-linear relationships (e.g., Caselli and Cunningham, 2009; Caselli and Tesei, 2011; Caselli, 2015). Thus, we explore such predictions by allowing functions $g($. and $f($.) to follow a polynomial of order two or more.

Notice we do not control for lags of canon or mining production in our specification. In the case of mining canon, there is evidence suggesting that mayors react to the transfers that they receive in any given year because not doing so could lead to higher political competition and higher likelihood that the central government will reduce transfers due to low budget execution (e.g., Maldonado, 2015; Ardanaz and Maldonado, 2016). Furthermore, in the case of mining production, previous studies have shown that the effect on market outcomes is contemporaneous (Jacobsen and Parker, 2014).

Changes in mining production could be correlated with unobserved variables that affect test scores, if for instance, mines are disproportionally located in poorer districts. In that case, our estimates of $g\left(m_{d t}\right)$ could be biased. We avoid this problem by focusing on the withindistrict variation on the value of production. Therefore, our identification comes from year-to-year changes in the value of production in the same district, including districts that become producers during the period of analysis. ${ }^{13}$ Also, the inclusion of time-fixed effects allows us to control for the possibility that unobserved factors alter test scores and mining production (as well as transfers) over time.

13 Only few districts become producers during the period of analysis. Eliminating them from our sample does not change our results (results available upon request). 
It is possible, however, that local governments may influence production decisions by investing in ways that attract mining companies. As before, if the traits influencing investment decisions are time-invariant our district fixed-effect model will account for such characteristics. Also, the fact that starting a new exploitation requires seven years, on average, reduces the possibility that such traits drive our findings (Maldonado, 2014). Indeed, a new exploitation that started as a consequence of the mining boom would appear only at the end or after our period of analysis. Furthermore, by law, local governments play no role in the process of granting mining rights. Thus, it is unlikely that our findings are affected by local governments influencing production decisions.

Barrantes et al. (2010) show that changes in the mining Canon Law were the product of circumstantial alliances between congressmen from mineral rich regions and not the result of pressure from regional and local actors or the executive power. However, these negotiations and changes in the law, took place in 2004, that is three years before our period of analysis. Moreover, these negotiations depended on time-invariant characteristics that are captured by our district-level fixed effects and thus, they provide further support to our identification approach. Holding the investment capacity of the local governments constant, by the use of district fixed effects, we explore whether the year-to-year variation in the amount of transfers and mining production helps in the formation of human capital measured by test scores. 

4. RESULTS

\subsection{Effect of mining production}

We start by considering the link between (the value of) mining production and student academic achievement ignoring, for the moment, the role of the canon. In Table 2 we show estimates of Equation (1) for math (Panel A) and reading (Panel B), when all fixed effects are included. We first consider a linear specification. For math, column (1), we find no significant association between mining production and student learning. The parameter is near zero both practically and statistically. When exploring a higher order polynomial (column 2) and the inclusion of school and children characteristics (columns 3 and 4) the results remain unchanged. The absence of a statistically significant effect is also evident when we study the effect on reading outcomes (Panel B).

In Appendix Tables $\mathrm{A} 1$ and $\mathrm{A} 2$ we consider four heterogeneous effects of mining production by the location and type of the schools: urban, rural, public and private. As shown in those tables, we find no association between mining production and student achievement in those subsamples either, except for the case of rural schools, where we find a negative and statistically significant effect $(\mathrm{p}<0.05)$, albeit very small in both math and reading (Table A2). This effect persists when considering a higher order polynomial and when including schools' and students' characteristics. Mining production has also a weak 
effect on math scores for urban schools, but this effect disappears after controlling for second-order polynomials and socio-economic characteristics. These findings suggest that, at best, the year-to-year variation in mining production has no effect on human capital accumulation, as measured by test scores.

\subsection{Effect of canon transfers}

We now consider the effect of the canon transfers on test scores. Table 3 displays our estimates. We start with a simple model for math and reading, using a linear specification and ignoring the effects of production but incorporating all the fixed effects. For both subjects, we find no association in this simplest model (column 1). However, a quadratic functional form suggests a nonlinear link for math but not for reading (column 2). For math, this pattern is consistent with the non-monotonic effects of resource booms highlighted by the political economy literature described earlier.

Adding controls for the value of mining production (column 3) as well as student and school characteristics (column 4) does not alter our findings: there are positive, statistically significant (but marginally decreasing) effects for math, and negligible impacts for reading. Consistent with our previous analysis, the coefficient for mining production is not statistically significant after controlling for canon and its square.

Considering column 4, where all controls are included, the testscore-maximizing amount of canon is about US\$ 5,500 per capita per year. Conditional of receiving a transfer, the 99-percentile value of canon transfers is only US\$1,313. Thus, for nearly all districts receiving canon, our findings suggest a positive effect of the transfers 
on math test scores. Moreover, given that the average transfer during the period of our analysis is US\$ 107 per capita for the sample of districts that received strictly positive transfers, our estimates suggest an increase of around 23.5 percent of a standard deviation in math scores at this point of the distribution.

To put our results in perspective, the average impact of the canon on test scores is higher than 83 percent of the studies reported by Kremer et al. (2013) who analyze primary school interventions evaluated with randomized control trials. For example, based on the authors' review, our effect is larger than all the studies where "business as usual" resources are provided (e.g., textbook, class size, flipcharts) and all but two of the pedagogical innovations. The latter is relevant because one of the studies on pedagogical innovation provides contracts to teachers (Duflo et al., 2012); as we will show below, one of the mechanisms that explain our findings is indeed the increase in the share of teachers with long-term contracts.

\subsection{Robustness checks}

\section{a. Relaxing the parametric quadratic specification}

The non-monotonic effects of mining canon on learning outcomes are consistent with the political economy arguments discussed earlier but they strongly rely on the use a quadratic parametric approximation. To evaluate whether this approach is consistent with the data, we extend the empirical model to include other polynomials and check whether they offer a better fit.

Table A3 in the Appendix presents the results of the analysis. Columns 1 to 3 replicate the results for the basic specification 
while we add cubic and quartic terms for mining canon in columns 4 and 5. As a benchmark, we first test whether the coefficients for the quadratic approximation are both equal to zero. We confidently reject the null hypothesis that both coefficients are equal to zero (F-statistic of 3.67 with a p-value of 0.03 ) for the case of math scores. For the case of the cubic and quadratic approximations, we implement a test for nested models in which the null hypothesis assumes that the quadratic approximation offers a better fit compared to alternative specifications. In both cases, we fail to reject the null: F-statistic of 0.73 with a p-value of 0.39 against the cubic specification and F-statistic of 0.59 with a p-value of 0.56 against the quartic one. Therefore, the evidence suggests that the quadratic approximation offers the best fit to the data. Similar results are obtained for reading (Panel B).

\section{b. Alternative samples of districts according to mining production}

One concern is that endogenous production responses may play a role even after controlling by mining production in the econometric specifications. To address this issue, we take advantage of the fact that the mining Canon Law establishes that non-producer districts located in a producing province also receive a fraction of the rent generated by mining exploitation. This allows us to test the impact of the redistribution of natural resource rents in settings where production externalities and production endogenous responses are not expected to play a role.

For this purpose, we limit the sample to non-producing districts located in a producing province. Table A4 in the Appendix presents the results. The coefficients are statistically significant 
and larger than those reported in Table 3 for the basic specification for math scores (Panel A, columns 1 and 2). This result is robust to controlling for student and school characteristics (column 3). As before, there is no effect for the case of reading scores (Panel B). Furthermore, in Table A5, we restrict the sample to non-producing districts but located in non-producing provinces. In this case, we find smaller positive impacts with diminishing marginal effects, but that are imprecise given the smaller variation in canon transfers. ${ }^{14}$

\section{c. Permutation tests}

To further validate our empirical strategy, we consider falsification tests by incorrectly assigning the time series of canon transfers and mining production, $\left\{c_{d v}, m_{d t}\right\}$, that belong to district $d$ to a randomly chosen district $j$ from the set of all districts in the country. If unobserved characteristics, beyond the ones controlled with the district and year fixed-effects, are behind our findings for the canon transfers, we should expect this permutation exercise to produce non-zero impacts. In Figure 3, we show the distributions for the linear and quadratic coefficients from 10,000 permutations, after controlling for mining production. This is the same specification used in Table 3, column (3), whose benchmark parameter is reproduced here as the vertical dashed lines to ease the comparison. As expected, in Panels A (linear) and B (quadratic) we clearly observe that the incorrect assignment of canon transfers

14 The coefficient of variation of the per-capita canon transfers for non-producing districts in non-producer provinces is 30 percent smaller compared to the variation for all other districts. 
produces estimates centered around zero (no effect). The original estimates are far away from these non-zero effects and they are unlikely to be generated by this (incorrect) random assignment given the shape of the density function. These results provide further evidence of the validity of the identifying assumptions for our empirical strategy. ${ }^{15}$

\subsection{Heterogeneous effects}

In Table 4 we report regressions exploring heterogeneous effects regarding the public-private and urban-rural divides. In column (1) we reproduce the results for the entire sample to ease comparisons. The quadratic relationship is present in all subsamples except for private schools. This result is consistent with the fact that mining production has very limited impact on local economic conditions and provides additional support to the hypothesis that the main driver factor is political since Peruvian mayors seem to use mining canon funds to improve learning conditions in public schools. We will provide additional evidence on this regard in the next section.

15 Note that the nature of the canon transfers makes it impossible to obtain valid inference if this incorrect random assignment is done when $j$ is obtained from the region or province where $d$ is located. As described in Section 2, districts in the same province or region of a producing district will receive a transfer that is correlated with the one received by district $d$. Thus, transfers to $d$ and its neighboring districts are not spurious as is the case where $j$ is drawn from any district in the country. In the Appendix, Figure A3, we show that when such permutations are done, the distribution of the incorrect permutations is not centered around zero. However, our estimates are away still located in low-probability regions for these distributions. 


\subsection{Mechanisms}

We now explore several mechanisms that could explain how the canon transfers increase academic performance, as measured by test scores. We do this by using the same identification strategy as before, but replacing the test scores outcomes in Equation (1) with new outcomes at the district, school and household level, depending on the dataset.

We start by testing whether transfers increase local government's expenditures on education (and cultural) items. In Table 5, column 1 , we show that canon transfers are positively associated with more education expenditure, using data at the district level. This effect is consistent with the results from Caselli and Michaels (2013), who find that oil windfalls in Brazil did increase local-government education expenditure. Also in Brazil, but in the late 1980s, Litschig and Morrison (2013) find a positive effect on local expenditure on education from intergovernmental transfers.

However, as discussed by Caselli and Michaels (2013), higher local expenditure on education is not a sufficient condition for better educational outcomes. For instance, while they find a positive effect on the education budget, there is no evidence that such expenditure translated into "measures of real outcomes" that led to material improvements (p. 224). Thus, we expand our set of outcomes to explore whether canon transfers created improvements in school infrastructure and the quality of teachers. Specifically, we use data from the Censo Escolar and test if variation in canon transfers relates to the hiring of teachers with long-term contracts (column 3), percentage of teachers with college degrees in education (columns 4) and basic infrastructure services in the school: electricity (column 5), water (column 6) and sanitation (column 7).

We find that the canon is positively and statistically significantly associated with long-term contracts for teachers as well as improving 
the access to electricity and sanitation in the schools. As shown in the Appendix, Tables A6 and A7, these effects are concentrated on rural and public schools. These findings also speak to the large literature about the role of resources on education outcomes (e.g., Hanushek, 1996; Glewwe and Kremer, 2006; Glewwe and Muralidharan, 2016). We also complement the work by Ferraz et al. (2012), who find that corruption has a negative effect on students' academic performance in Brazil as politicians deviate resources away from education.

In column (2) of Table 5 we rule out the possibility that population effects drive improvements in test scores. We find no effect on school enrollment from canon transfers, suggesting that larger windfalls did not seem to attract families with children. ${ }^{16}$ This is consistent with the work of Aragón and Rud (2013) who focused on Yanacocha, a large gold mine in Northern Peru. The authors also find no changes in the composition of the labor force-measured by education, gender and portfolio of crops - using a difference-in-difference approach.

Yet, Loayza and Rigolini (2016), using the 2007 Peruvian population census, find that areas with mining booms attracted skilled migrants. Our results showing no effect on school enrollment could still be consistent with the Loayza and Rigolini's findings, if migrants are not coming with their families. Such migration pattern would be consistent with a household division of labor aimed at maximizing earnings from work opportunities (e.g., Chant, 1991; Hugo, 2003, 2006). Also, Loayza and Rigolini's analysis uses only data from 2007, which is the starting of our period of analysis. Thus, if skilled migration were temporary, circular, or concentrated at the beginning of the boom, our results would also be consistent with theirs. Furthermore, they

16 Consistent with our previous results, we find no impact on enrollment for the case of public schools. However, we do find a non-monotonic effect in enrollment for the case of private schools. 
base their empirical design on a cross-sectional variation that does not necessarily allow them to account for unobserved factors related to both, migration and mining production (or canon transfers). We base our design, in contrast, on a difference-in-difference approach, which avoids such a possibility; thus our research strategy could also explain these different findings.

We now use household-level data from EnAHo to investigate whether changes in living standards at home also act as potential mechanisms (Table 6). This analysis complements and expands previous findings exploring the impacts of production and canon on consumption and poverty using census data (Loayza and Rigolini, 2016), household surveys (Aragón and Rud, 2013) and both (Zambrano et al, 2014).

For Table 6 we merge the ENAHO household surveys from 2007 to 2012 with the canon and mining datasets. In column (1) we show that there is a decline in adults' unemployment status (aged between 14 and 65) when transfers increase. ${ }^{17}$ In column (2) we find that this employment surge seems to occur due to an increase in public employment, although the relationship is non-monotonic, a result consistent with the idea that politicians use public employment as an instrument to obtain political support. ${ }^{18}$ Other papers focused on Peru, cited above, did not explore these outcomes, so it is not possible to compare our findings with theirs. As shown in Table A8, in the Appendix, these results are mainly driven by schools in rural areas.

We then explore the effects of canon transfers on per capita consumption (column 4) and income (column 5). In these two cases,

17 In the ENAHO, employment is defined for individuals 14 years of age or older.

18 Robinson, Torvik and Verdier (2006) have highlighted this mechanism from a theoretical point of view. Maldonado (2015) provides evidence on this regard for the Peruvian case for a different period than the one covered in this paper. 
we do not find an effect. This null effect is not new. Aragón and Rud (2013) and Zambrano et al. (2014), suggests that, if any, the effects of windfalls on these outcomes tend to be concentrated at the bottom of their distributions. ${ }^{19}$ These authors observe a negative relationship between canon transfers and poverty and inequality, when comparing districts in 2007 and 2011, nationwide.

Furthermore, we evaluate whether canon transfers, through the expansion of the public education budget, created a crowding-out effect on household's education expenditures. As discussed by Todd and Wolpin (2003), parents could alter their behavior when more resources are brought to their children's schools, affecting the evaluation of education policies. In particular, previous work (e.g., Das et al., 2013) has shown that parents reduce education expenditures when schools receive more (unanticipated) funds. ${ }^{20}$ We test for evidence of crowding-out behavior in column (3) of Table 6, where the outcome is now household education expenditure per-student, using ENAHO. We do not find evidence of crowding-out at the household level, suggesting that parents do not see their inputs as substitutes with respect to school-based inputs. ${ }^{21}$

Finally, also using the EnAHo, we test whether the canon improves health conditions of adults and children (aged 6-10). As discussed by Litschig and Morrison (2013), investigating the impact of intergovernmental transfers on health outcomes is a natural step when understanding whether such transfers could improve human capital.

19 Our null effects on consumption and income do differ from Loayza and Rigolini (2016), but as explained above, these disparities could arise from differences in methodological approaches and period of analysis.

20 See also Pop-Eleches and Urquiola (2013) for an empirical applications showing evidence of crowding-out in parental behavior when students go a better school.

21 See Litschig and Morrison (2013) for a discussion of the "flypaper effect" and crowding out on own revenue and other revenue sources among local governments in the presence of intergovernmental transfers 
In Table 7 we consider three (self-reported) indicators: having health complications in the last four weeks, whether the individual felt sick in the last four weeks and the number of days an individual between 15 and 64 years of age that could not work due to being sick. Our results indicate that canon transfers are associated with health improvements. We observe a decline in the probability of experiencing health complications for adults and children (columns 1 and 2), as well as a decline in the probability of being sick recently (but for adults only, column 3). The results are essentially the same for urban and rural areas (Table A9 in the Appendix). 

We studied whether booms of natural resources affect human capital accumulation, exploiting a natural experiment in Peru's mining sector, a country with low governance indicators. In general, this is a challenging task because it is difficult to isolate possible unobserved factors affecting the resource booms - and their redistribution - as well as human capital investments. Furthermore, from a theoretical point of view, the effects are ambiguous. For instance, changes in mining production can improve labor market opportunities, making it possible for households to invest more in education, but it can also affect students' performance if they generate negative environmental and health-related externalities.

On the other hand, the literature has linked resource booms to increases in natural resource rents to local governments, implying an increasing access to fiscal funds that incumbents could use to build schools, hire better teachers and distribute school inputs.

We find non-monotonic effects of the redistribution of mining rents on math scores, but no effect for the case of reading. The former effect is positive and large: 0.23 standard deviations for the average municipality, implying that the mining boom in Peru has been beneficial for students in almost all recipient localities. The net effect is negative only for extremely canon-rich municipalities (top 1\% in terms of mining canon distribution). These results are in line with recent scholarship documenting non-monotonic and perverse effects 
for natural resource-rich regions. This evidence is also consistent with a political economy argument where mayors invest in public goods when they expect to keep power, but underinvest when they face less political competition. In fact, we find that these effects are mainly driven by public schools and by changes in school-level conditions such as infrastructure and better labor conditions for teachers. These are ways in which incumbents can invest mining canon transfers.

We did not find impacts of mining production on learning outcomes. This result is important, since it helps to identify the causal mechanism as a political one when redistributive mechanisms are in place. The redistribution fueled by the resource boom had a limited impact on improving households' economic conditions, with a weak impact on reducing unemployment. Interestingly, only public employment reacted to the boom, congruent with a theoretical mechanism that indicates that politicians use public employment as a clientelistic tool to obtain political support. The non-monotonic effect found for public employment is consistent in this regard.

In addition, we also find non-monotonic effects for the case of health variables. These results can be a consequence of improvements in the quality and access to health facilities, something that has been documented in other studies (Ardanaz and Maldonado 2016; Maldonado 2015).

The evidence presented in this paper puts into question some beliefs in the literature about the role of natural resources in development. Recent studies have emphasized that natural resources can be a "blessing" only when good institutions are available. However, we have shown that a natural resource boom can lead to an increase of human capital accumulation in a context of poor institutions, but only when mechanisms of distribution of natural resource windfalls are in place. Moreover, we find that only extremely canon-rich municipalities 
experience negative effects of a resource boom. This may explain the anecdotal evidence of the resource curse literature, typically motivated by highlighting the economic and political distortions experienced by extreme natural wealth in the Middle East or Africa. Thus, natural resources can lead to a curse only for extremely natural resource-rich societies, and it can potentially be a blessing for the rest.

Undoubtedly, the effect of natural resource booms on academic achievement deserves further research, in particular under different institutional set-ups and windfalls-redistribution schemes. Focusing on the Peruvian case, perhaps one important question that remains open for discussion is: What are the long-term effects of mining production on the social outcomes here analyzed once the boom ends? Jacobsen and Parker (2014) find long-lived negative effects in the labor markets after the end of the 1970s gas and oil bonanza in the United States. However, we have not seen evidence documenting the long-run effects on human capital formation after the bust. Another question that remains open to consideration is the identification of the heterogeneous impact of canon on different test subjects. As documented, we observe an impact of canon transfers on math test scores, but not on reading scores. This deserves further research. 

REFERENCES

Angrist, J., and Kugler, A. (2008). Rural windfall or a new Resource curse?: coca, income, and civil conflict in Colombia. Review of Economics and Statistics, 90(2), 191-215

Aragón, F. M., Chuhan-Pole, P., and Land, B. C. (2015). The local economic impacts of resource abundance: what have we learned? World Bank Policy Research Working Paper, 7263. World Bank.

Aragón, F. M., and Rud, J. P. (2013). Natural resources and local communities: evidence from a Peruvian gold mine. American Economic Journal: Economic Policy, 5(2), 1-25.

Ardanaz, M., and Maldonado, S. (2016). Natural resource windfalls and efficiency of local government expenditures: evidence from Peru. Documentos de Trabajo, 014578. Universidad del Rosario.

Arellano-Yanguas, J. (2008). A thoroughly modern resource curse? the new natural resource policy agenda and the mining revival in Peru. Working Paper, 300. Institute for Development Studies.

Arellano-Yanguas, J. (2011). Aggravating the resource curse: decentralization, mining and conflict in Peru. The Journal of Development Studies, 47(4), 617-638.

Barrantes, R, Tanaka, M., Vera, S., and Perez-Leon, M. (2010). El boom de los recursos naturales y las coaliciones presupuestarias: una ilustración del caso peruano. Unpublished manuscript, Instituto de Estudios Peruanos, Lima, Perú. 
Birdsall, N., T. Pinckney, and R. Sabot. (2001). Natural resources, human capital and growth. In R. M. Auty (Ed.). Resource abundance and economic development (pp.57-75). Oxford University Press.

Brosio, G., and Jimenez, J. (2012). Decentralization and reform in Latin America: improving intergovernmental relations. Cheltenham, UK: Edward Elgar.

Calvo-Gonzalez, O., Apostolou, A., Aviles, A., Casas, C., Chacon, P., Cunha, B., Eaton, K., Illescas, J., Kaiser, K., Mayuri, M., Ortiz, D., and Yokoyama, E. (2010). Peru: the decentralization process and its links with public expenditure efficiency. World Bank.

Canavire-Bacarreza, G., Martinez-Vazquez, J. and Sepulveda, C. (2012). Sub-national revenue mobilization in Peru. International Center for Public Policy Working Paper Series, 12-09. Atlanta: International Center for Public Policy and Andrew Young School of Policy Studies. Georgia State University.

Caselli, F. (2015). Power struggles and the natural resource curse. Unpublished manuscript, London School of Economics, London.

Caselli, F., and Michaels. G. (2013). Do oil windfalls improve living standards?: evidence from Brazil. American Economic Journal: Applied Economics, 5(1), 208-238

Caselli, F., and Cunningham, T. (2009). Leader behaviour and the natural resource curse. Oxford Economic Papers, 61(4), 628-650.

Caselli, F., and Tesei, A. (2011). Resource windfalls, political regimes, and political stability. Review of Economics and Statistics, 98(3), 573-590.

Chant S. (1991). Gender, migration and urban development in Costa Rica: the case of Guanacastle. Geoforum, 22(3), 237-253 
Das, J., Dercon, S., Habyarimana, J., Krishnan, P., Muralidharan, K., and Sundararaman, V. (2013). School inputs, household substitution, and test scores. American Economic Journal: Applied Economics, 5(2), 29-57.

Deacon, R.T. (2011). The political economy of the natural resource curse: a survey of theory and evidence. Foundations and Trends in Microeconomics, 7(2), 111-208.

Dell, M. (2010). The persistent effects of Peru's mining mita. Econometrica, 78(6), 1863-1903.

Duflo, E., Dupas, P., and Kremer, M. (2015). School governance, teacher incentives, and pupil-teacher ratios: experimental evidence from Kenyan primary schools. Journal of Public Economics, 123, 92-110.

Ferraz, C., Finan, F., and Moreira, D. B. (2012). Corrupting learning: evidence from missing federal education funds in Brazil. Journal of Public Economics, 96(9), 712-726.

Glewwe, P. and Kremer, M. (2006). Schools, teachers, and education outcomes in developing countries. In Handbook of the Economics of Education, 2 (pp. 945-1017).

Glewwe, P. and Muralidharan, K. (2016) Improving education outcomes in developing countries: evidence, knowledge gaps, and policy implications. In Handbook of the Economics of Education, 5 (pp. 653-743).

Gylfason, T. (2001). Natural resources, education and economic development. European Economic Review, 45(4-5), 847-859.

Gylfason, T., and Zoega, G. (2006). Natural resources and economic growth: the role of investment. The World Economy, 29(8), 10911115. 
Hanushek, E. A. (2006). School resources. In Handbook of the Economics of Education, 2, (pp. 865-908).

Hanushek, E. A., and Woessmann, L. (2012). Do better schools lead to more growth?: cognitive skills, economic outcomes, and causation. Journal of Economic Growth, 17(4), 267-321.

Hanushek, E. and Woessmann, L. (2010). Education and economic growth. In Dominic J. Brewer and Patrick J. McEwan (Eds.). Economics of education (pp.60-67). Amsterdam: Elsevier.

Hugo, G. (2003). Circular migration: keeping development rolling? Migration Policy Institute. Retrieved from http://www.migrationinformation.org/Feature/print.cfm?ID=129

Hugo, G. (2006). Temporary migration and the labour market in Australia. Australian Geographer, 37(2), 211-231

Jacobsen, G. D., and Parker, D. P. (2014). The economic aftermath of resource booms: evidence from boomtowns in the American West. The Economic Journal, 126(593), 1092-1128.

Kaufmann, D., Kraay, A., \& Mastruzzi, M. (2011). The worldwide governance indicators: methodology and analytical issues. Hague Journal on the Rule of Law, 3(2), 220-246.

Kremer, M., Brannen, C., and Glennerster, R. (2013). The challenge of education and learning in the developing world. Science, 340(6130) 297-300.

Kronenberg, T. (2004). The curse of natural resources in the transition economies. Economics of Transition, 12(3), 399-426.

Litschig, S., and Morrison, K. (2013). The impact of intergovernmental transfers on education outcomes and poverty reduction. American Economic Journal: Applied Economics, 5(4), 206-240. 
Loayza, N., and Rigolini, J. (2016). The local impact of mining on poverty and inequality: evidence from the commodity boom in Peru. World Development, 84, 219-234

Maldonado, S. (2014). The political effects of resource booms: political outcomes, clientelism and public goods provision in Peru. Unpublished Manuscript, University of California, Berkeley.

Maldonado, S. (2015). Resource booms and political support: evidence from Peru. Unpublished Manuscript University of California, Berkeley.

Polastri, R, and Rojas, F. (2007). Descentralización. In M. Giugale, V. Fretes-Cibils, and J. L. Newman. Perú. La oportunidad de un pais diferente: próspero, equitativo y gobernable (pp. 757-773). Lima: Banco Mundial.

Pop-Eleches, C., and Urquiola, M. (2013). Going to a better school: effects and behavioral responses. The American Economic Review, 103(4), 1289-1324.

Robinson, J, Torvik R., and Verdier, T. 2006. Political foundations of the resource curse. Journal of Development Economics, 79, 447-468.

Ross, M. (2014). What have we learned about the resource curse? Annual Review of Political Science, 18, 239-259

Rosser, A. (2006). The political economy of the resource curse: a literature survey. IDS Working Paper, 268. Brighton, UK: Institute of Development Studies.

Stevens, P. (2003). Resource impact: curse or blessing?: a literature survey. Journal of Energy Literature, 9(1), 1-42.

Todd, P. E., and Wolpin, K. I. (2003). On the specification and estimation of the production function for cognitive achievement. The Economic Journal, 113(485), 3-33. 
USGS. (2015). Mineral commodity summaries 2015. Retrieved from http://minerals.usgs.gov/minerals/pubs/mcs/2015/mcs2015.pdf van der Ploeg, F. (2011). Natural resources: curse or blessing? Journal of Economic Literature, 49(2), 366-420.

Zambrano, O, Robles, M., and Laos, D. (2014). Global boom, local impacts: mining revenues and subnational outcomes in Peru 20072011. IDB Working Paper Series, 509. Washington, DC: IDB

Zegarra, E., Orihuela, J., and Paredes, M. (2006). Minería y economías familiares: explorando impactos y espacios de conflicto. Proyecto Mediano CIES, 12, periodo 2005-2006. 


\section{APPENDIX}

Table 1

\section{Descriptive statistics. Averages 2007-2012}

\begin{tabular}{|c|c|c|c|}
\hline & $\begin{array}{l}\text { Producing } \\
\text { districts } \\
\text { (1) }\end{array}$ & $\begin{array}{l}\text { Non-producing } \\
\text { districts in } \\
\text { producing } \\
\text { provinces } \\
(2)\end{array}$ & $\begin{array}{c}\text { Non-producing } \\
\text { districts in } \\
\text { non-producing } \\
\text { provinces } \\
\text { (3) }\end{array}$ \\
\hline \multicolumn{4}{|c|}{ A. Learning, as measured by "Evaluación Censal de Estudiantes" (score) } \\
\hline Average scores in mathematics & 517.06 & 534.04 & 509.17 \\
\hline Average scores in reading & 514.73 & 532.49 & 508.46 \\
\hline Number of students & 110868 & 409626 & 1565804 \\
\hline \multicolumn{4}{|c|}{ B. Schools' characteristics, as measured by "Censo Escolar" (\%) } \\
\hline Teachers with long-term contract & 28.56 & 31.23 & 27.79 \\
\hline \multicolumn{4}{|c|}{ Teachers with a tertiary education degree } \\
\hline in a school teaching program & 97.44 & 97.08 & 94.54 \\
\hline Schools with access to electricity & 71.24 & 74.96 & 60.48 \\
\hline Schools with access to water & 65.86 & 68.97 & 54.96 \\
\hline Schools with access to sanitation & 74.83 & 76.46 & 72.12 \\
\hline Number of schools & 5794 & 22771 & 83361 \\
\hline \multicolumn{4}{|l|}{ C. Districts' characteristics } \\
\hline Mining production per-capita $\dagger$ & 15513 & 0.00 & 0.00 \\
\hline Canon transfers per-capita $\dagger$ & 0.37 & 0.19 & 0.04 \\
\hline Number of districts & 128 & 554 & 1156 \\
\hline
\end{tabular}

$\dagger$ Thousands of USD at constant prices of 2010, divided by total population at the district level. The total number of habitants for each district and year are obtained from Peru's National Bureau of Statistics (INEI). Source: Authors' calculations based on data from Peru's Ministries of Education, of Finance, of Energy and Mines, and INEI. 


\section{Table 2}

\section{Effects of mining production on academic achievement}

\section{Dependent variable: Test scores}

(1)

\section{Panel A. Math scores}

Mining production

(3)

(4)

\begin{tabular}{|c|c|c|c|c|}
\hline \multirow[t]{2}{*}{ Mining production } & 0.0000 & 0.0001 & 0.0001 & 0.0001 \\
\hline & $(0.0001)$ & $(0.0002)$ & $(0.0002)$ & $(0.0002)$ \\
\hline \multirow[t]{2}{*}{ Mining production squared } & & -0.0000 & -0.0000 & -0.0000 \\
\hline & & $(0.0000)$ & $(0.0000)$ & $(0.0000)$ \\
\hline R-squared & 0.0062 & 0.0062 & 0.0146 & 0.0171 \\
\hline Number of students & $2,072,339$ & $2,072,339$ & $2,016,774$ & $2,012,798$ \\
\hline \multicolumn{5}{|l|}{ Panel B. Reading scores } \\
\hline \multirow[t]{2}{*}{ Mining production } & -0.0001 & 0.0001 & 0.0001 & 0.0001 \\
\hline & $(0.0001)$ & $(0.0001)$ & $(0.0001)$ & $(0.0001)$ \\
\hline \multirow[t]{2}{*}{ Mining production squared } & & $-0.0000^{* *}$ & $-0.0000^{*}$ & $-0.0000^{* *}$ \\
\hline & & $(0.0000)$ & $(0.0000)$ & $(0.0000)$ \\
\hline R-squared & 0.0266 & 0.0266 & 0.0509 & 0.0638 \\
\hline Number of students & $2,068,271$ & $2,068,271$ & $2,011,922$ & $2,008,941$ \\
\hline Student controls & $\mathrm{N}$ & $\mathrm{N}$ & $\mathrm{Y}$ & $\mathrm{Y}$ \\
\hline School controls & $\mathrm{N}$ & $\mathrm{N}$ & $\mathrm{N}$ & $\mathrm{Y}$ \\
\hline
\end{tabular}

Note: Robust standard errors clustered at the district level in parentheses. * Significant at ten percent; ${ }^{* *}$ significant at five percent; ${ }^{* * *}$ significant at one percent. Mining corresponds to the value of mining production per-capita, in thousands of USD at constant prices of 2010. All regressions include fixed effects at the district level and by year. School characteristics include: school day (full-day, half-day morning or half-day afternoon); school administration type (public/private), and school type (one-teacher school/full grade). Student characteristics include: gender and mother language (Spanish/other) of the children. Source: Authors' calculations based data from Peru's Ministries of Education, of Finance, of Energy and Mines, and INEI. 


\section{Table 3}

\section{Effects of canon on academic achievement}

\section{Dependent variable: Test scores}

(1)

6.9139

$21.6714^{* *}$

$21.7054^{* *}$

(9.5905)

(4.6448)

$-1.9654^{* *}$

(9.6360)

(0.8429)

$-1.9679^{* *}$

(0.8453)

$-0.0000$

(0.0001)

$0.0062 \quad 0.0062$

0.0062

$2,072,339$

$2,072,339$

$2,072,339$

(4)

R-squared

Panel B. Reading scores

Canon

$$
-0.6112
$$

$-2.6721$

$-2.5545$

$-2.8542$

(1.7751)

(4.3260)

(4.3682)

(4.5153)

Canon squared

$$
0.2743
$$

0.2656

0.2731

(0.3728)

(0.3743)

(0.3848)

Mining production

$-0.0001$

$-0.0001$

$(0.0001)$

(0.0001)

R-squared

$$
0.0266
$$

0.0266

0.0266

0.0638

Number of students

2,068,271

$2,068,271$

$2,068,271$

$2,007,595$

Student controls

School controls

$\begin{array}{ll}\mathrm{N} & \mathrm{N} \\ \mathrm{N} & \mathrm{N}\end{array}$

Y
Y

Note: Robust standard errors clustered at the district level in parentheses. ${ }^{*}$ Significant at ten percent; ${ }^{* *}$ significant at five percent; ${ }^{* * *}$ significant at one percent. Mining and canon correspond to the value of mining production per-capita and canon per-capita, in thousands of USD at constant prices of 2010. All regressions include fixed effects at the district level and by year. School characteristics include: school day (full-day, half-day morning or half-day afternoon); school administration type (public/private), and school type (one-teacher school/ full grade). Student characteristics include: gender and mother language (Spanish/other) of the children. Source: Authors' calculations based data from Peru's Ministries of Education, of Finance, of Energy and Mines, and INEI. 


\section{Table 4}

\section{Heterogeneous effects of canon on academic achievement}

\begin{tabular}{|c|c|c|c|c|c|}
\hline \multicolumn{6}{|c|}{ Sample } \\
\hline & $\begin{array}{l}\text { All } \\
(1)\end{array}$ & $\begin{array}{c}\text { Urban } \\
(2)\end{array}$ & $\begin{array}{c}\text { Rural } \\
(3)\end{array}$ & $\begin{array}{c}\text { Private } \\
(4)\end{array}$ & $\begin{array}{c}\text { Public } \\
\text { (5) }\end{array}$ \\
\hline \multicolumn{6}{|l|}{ Panel A. Math scores } \\
\hline Canon & $\begin{array}{c}24.0105^{* *} \\
(9.4667)\end{array}$ & $\begin{array}{l}25.2195^{* *} \\
(11.2634)\end{array}$ & $\begin{array}{c}20.6906^{* *} \\
(9.8223)\end{array}$ & $\begin{array}{c}-3.6998 \\
(17.1192)\end{array}$ & $\begin{array}{c}25.6681^{* * *} \\
(9.2483)\end{array}$ \\
\hline Canon squared & $\begin{array}{c}-2.1754^{* * *} \\
(0.8285)\end{array}$ & $\begin{array}{c}-2.2646^{* *} \\
(0.9788)\end{array}$ & $\begin{array}{c}-2.0861^{* *} \\
(0.8627)\end{array}$ & $\begin{array}{l}-0.1889 \\
(1.2898)\end{array}$ & $\begin{array}{c}-2.2894^{* * *} \\
(0.8677)\end{array}$ \\
\hline Mining production & $\begin{array}{l}-0.0000 \\
(0.0001)\end{array}$ & $\begin{array}{c}0.0002 \\
(0.0001)\end{array}$ & $\begin{array}{c}0.0001 \\
(0.0003)\end{array}$ & $\begin{array}{c}0.0001 \\
(0.0003)\end{array}$ & $\begin{array}{c}0.0001 \\
(0.0003)\end{array}$ \\
\hline R-squared & 0.0172 & 0.0164 & 0.0142 & 0.0170 & 0.0146 \\
\hline Number of students & 2012798 & 1353896 & 653410 & 299441 & 1713357 \\
\hline Panel B. Reading scon & & & & & \\
\hline Canon & $\begin{array}{l}-2.8542 \\
(4.5153)\end{array}$ & $\begin{array}{c}0.0939 \\
(4.5661)\end{array}$ & $\begin{array}{c}0.7575 \\
(7.5111)\end{array}$ & $\begin{array}{l}-23.603^{* *} \\
(10.6427)\end{array}$ & $\begin{array}{c}1.2046 \\
(4.6143)\end{array}$ \\
\hline Canon squared & $\begin{array}{c}0.2731 \\
(0.3848)\end{array}$ & $\begin{array}{l}-0.0277 \\
(0.3881)\end{array}$ & $\begin{array}{l}-0.0073 \\
(0.6579)\end{array}$ & $\begin{array}{l}1.9557^{* *} \\
(0.7954)\end{array}$ & $\begin{array}{l}-0.1657 \\
(0.4108)\end{array}$ \\
\hline Mining production & $\begin{array}{l}-0.0001 \\
(0.0001)\end{array}$ & $\begin{array}{c}0.0001 \\
(0.0001)\end{array}$ & $\begin{array}{l}-0.0000 \\
(0.0001)\end{array}$ & $\begin{array}{l}-0.0000 \\
(0.0001)\end{array}$ & $\begin{array}{l}-0.0000 \\
(0.0001)\end{array}$ \\
\hline R-squared & 0.0638 & 0.0554 & 0.0319 & 0.0333 & 0.0512 \\
\hline Number of students & 2008941 & 1351621 & 651838 & 299302 & 1709639 \\
\hline
\end{tabular}

Note: Robust standard errors clustered at the district level in parentheses. ${ }^{*}$ Significant at ten percent; ${ }^{* *}$ significant at five percent; ${ }^{* * *}$ significant at one percent. Mining and canon correspond to the value of mining production per-capita and canon per-capita, in thousands of USD at constant prices of 2010. All regressions include fixed effects at the district level and by year. School characteristics include: school day (full-day, half-day morning or half-day afternoon); school administration type (public/private), and school type (one-teacher school/ full grade). Student characteristics include: gender and mother language (Spanish/other) of the children. Source: Authors' calculations based data from Peru's Ministries of Education, of Finance, of Energy and Mines, and INEI. 


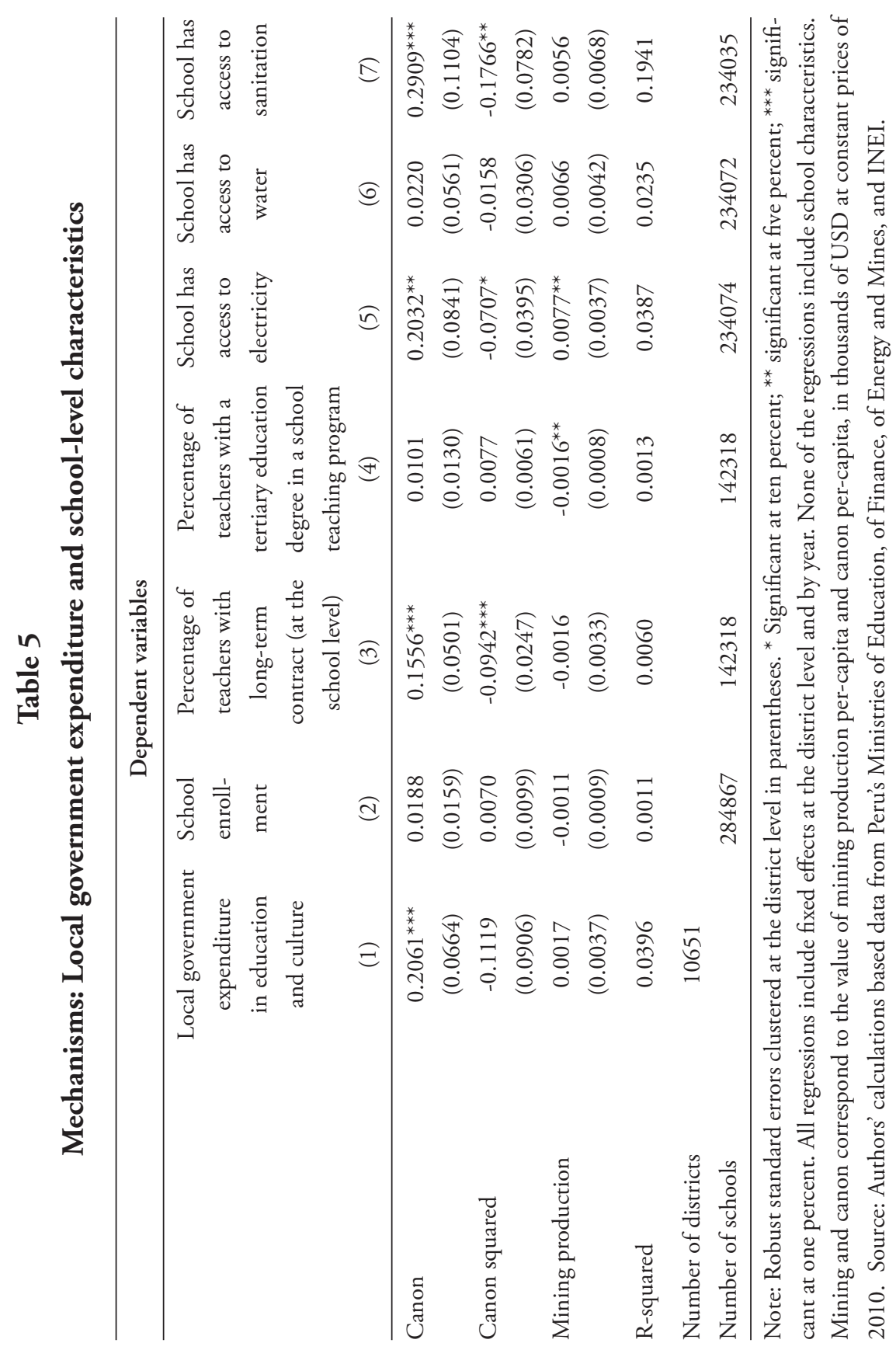




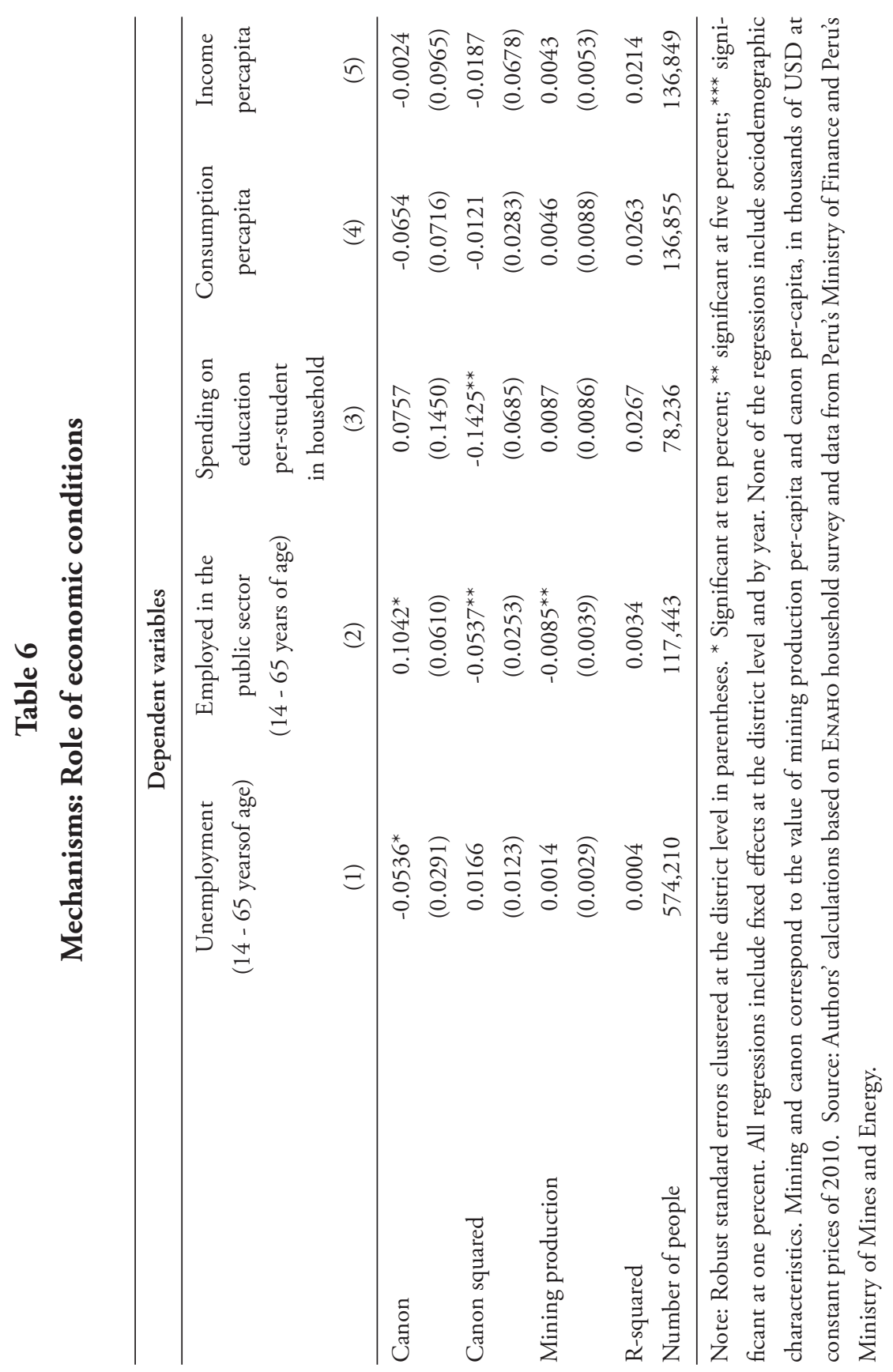




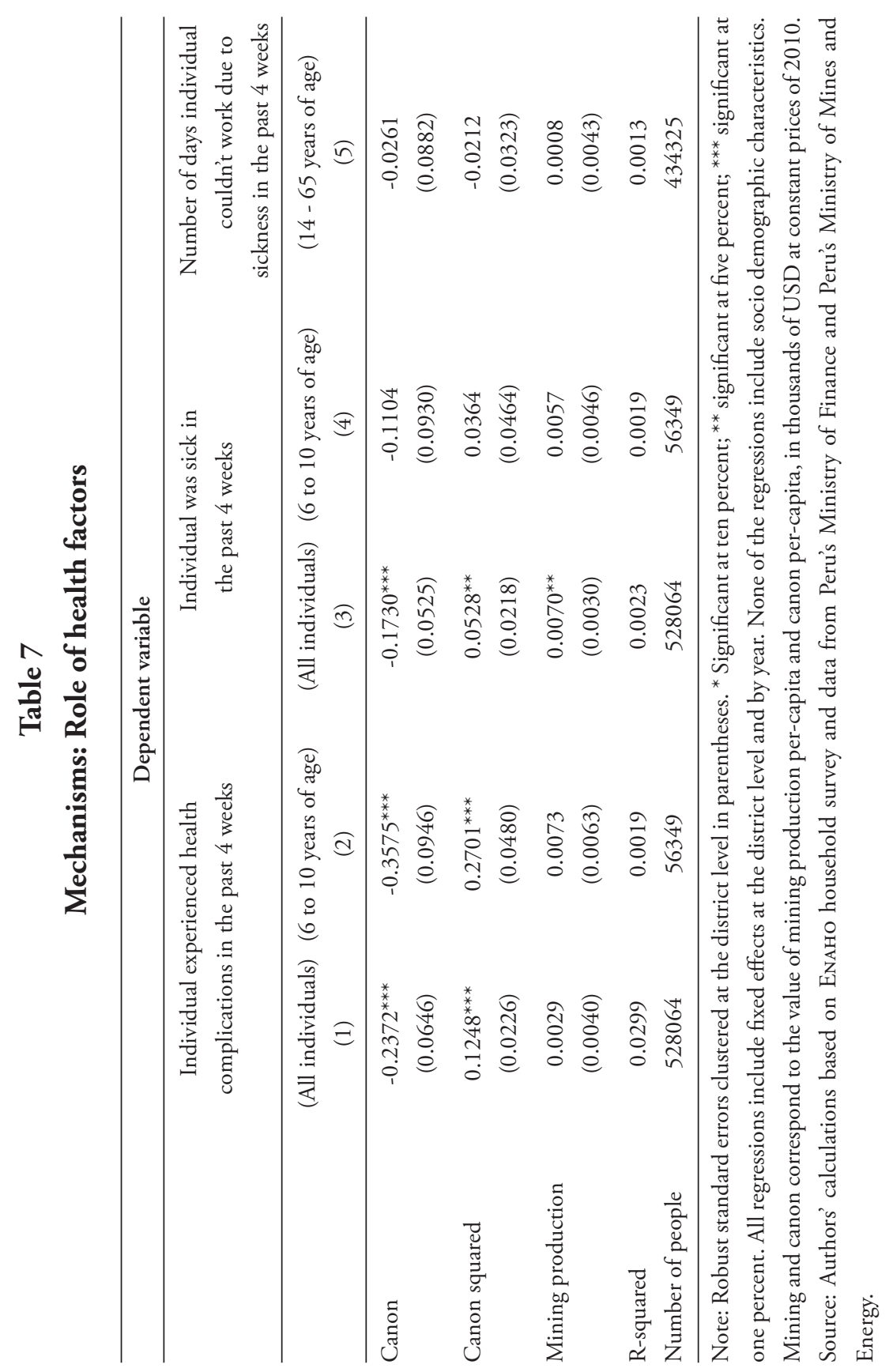




\section{Figure 1}

\section{Natural resources and test scores}

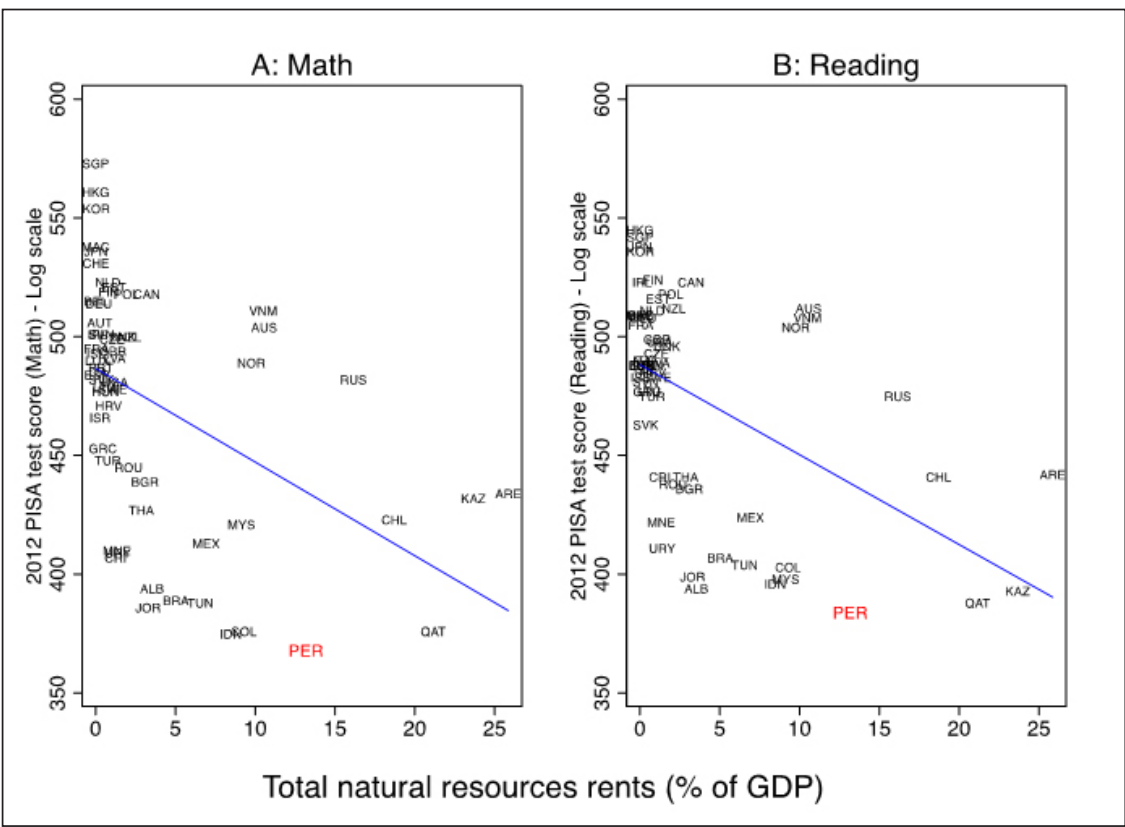

Note: Data for the test scores come from the 2012 PISA and the share of GDP from total natural resources (2011-2012 average) comes from the World Bank's World Development Indicators (code: NY.GDP.TOTL.RT.ZS) and represents the sum of rents from oil, natural gas, coal (hard and soft), mineral, and forest. Data for this graph can be downloaded from http:// www.oecd.org/pisa/ and http://databank.worldbank.org/data/reports.aspx?source=world-development-indicators 


\section{Figure 2}

\section{Spending per student in primary education and test scores}
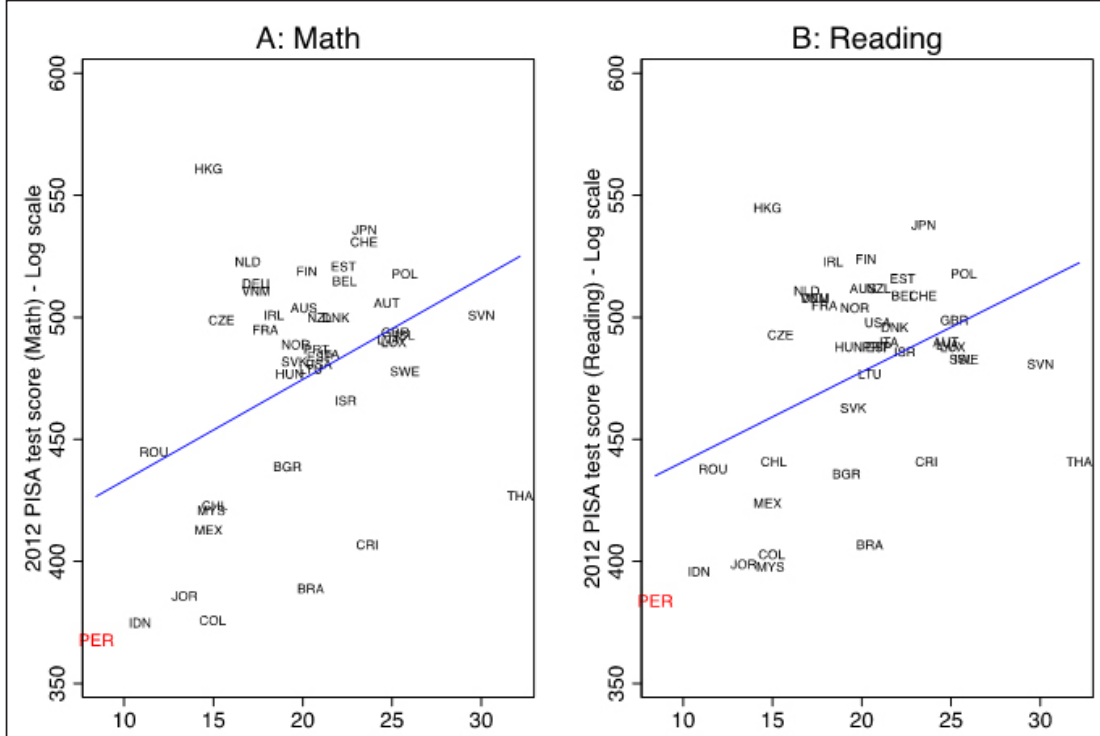

Government expenditure per student, primary (\% of GDP per capita)

Note: Data for the test scores come from the 2012 PISA and the share of GDP from government expenditure in primary education per student (2011-2012 average) comes from the World Bank's World Development Indicators (code: SE.XPD.PRIM.PC.ZS) and includes current, capital, and transfers. Data for this graph can be downloaded from http://www.oecd. org/pisa/ and http://databank.worldbank.org/data/reports.aspx?source=world-developmentindicators 


\section{Figure 3}

Mining canon transfer randomizations

\section{A. Kernel density estimate for the coefficient of canon}

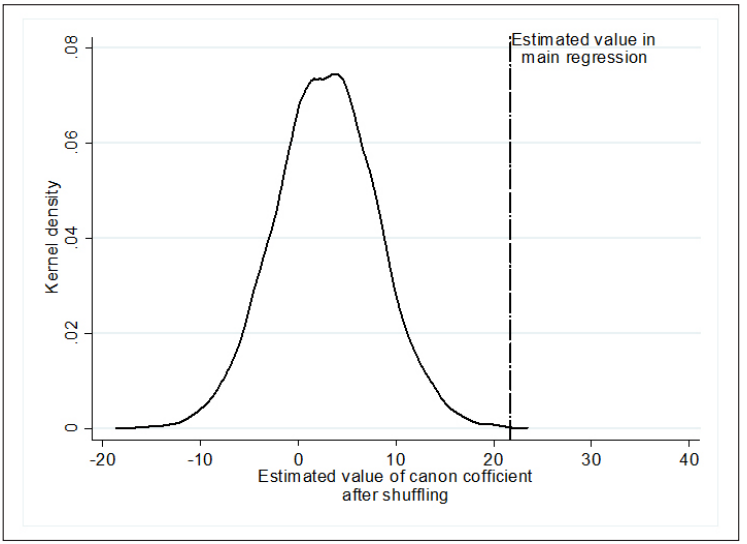

\section{B. Kernel density estimate for the coefficient of canon squared}

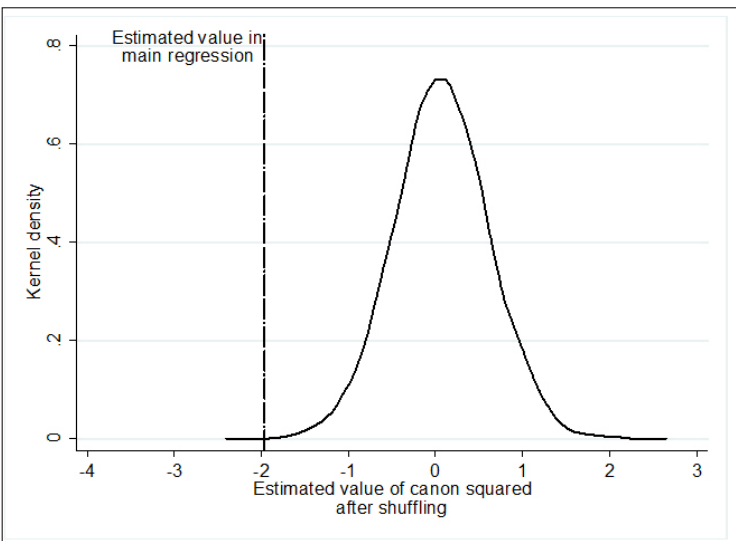

Bandwidth: 0.2

Note: In the corresponding regressions, mining and canon correspond to the value of mining production per-capita and canon per-capita, in thousands of USD at constant prices of 2010. All regressions include fixed effects at the district level and by year. The regressions do not include school characteristics or student characteristics. Source: Authors' calculations based data from Peru's Ministries of Education, of Finance, of Energy and Mines, and INEI. 


\section{Online Appendix - Not for publication}

Figure A

\section{Trends in mining exports}

A. Total mining exports, 2000-2015

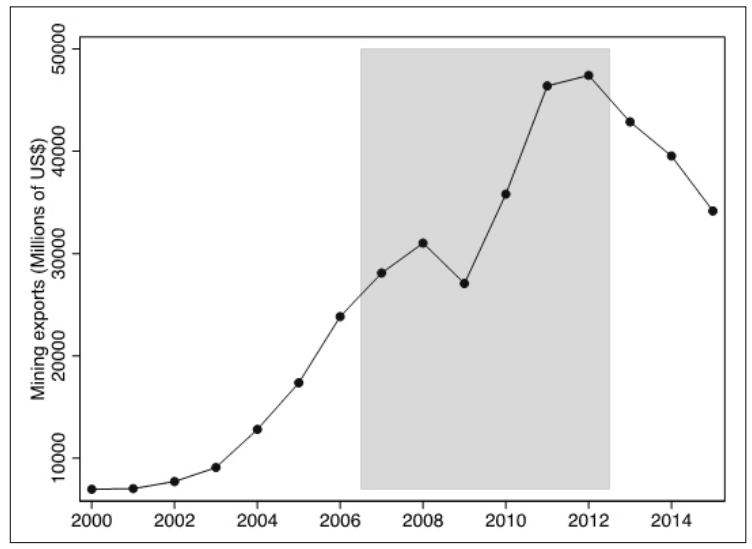

B. Exports by mineral, 2006-2012

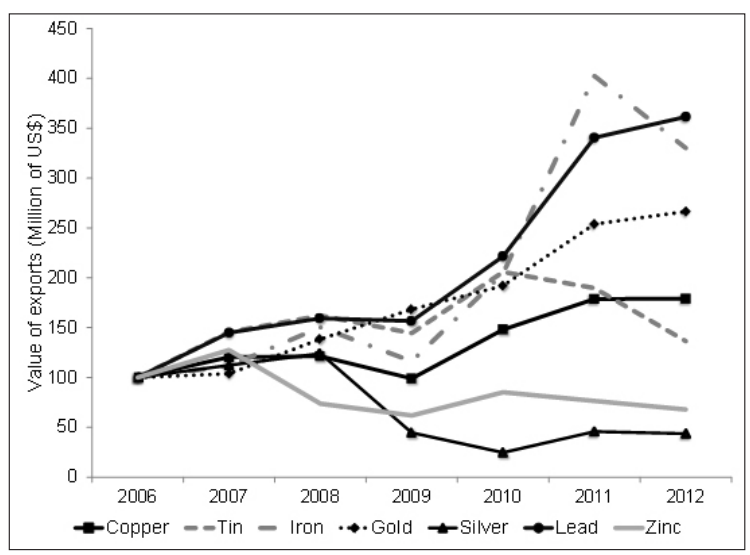

Note: Shaded area (Panel A) indicates the period of analysis (2007-2012). Data for this graph can downloaded from http://www.bcrp.gob.pe/. 


\section{Figure A2}

\section{Trends in canon transfers}

\section{A. Total canon transfers: $2000-2015$}

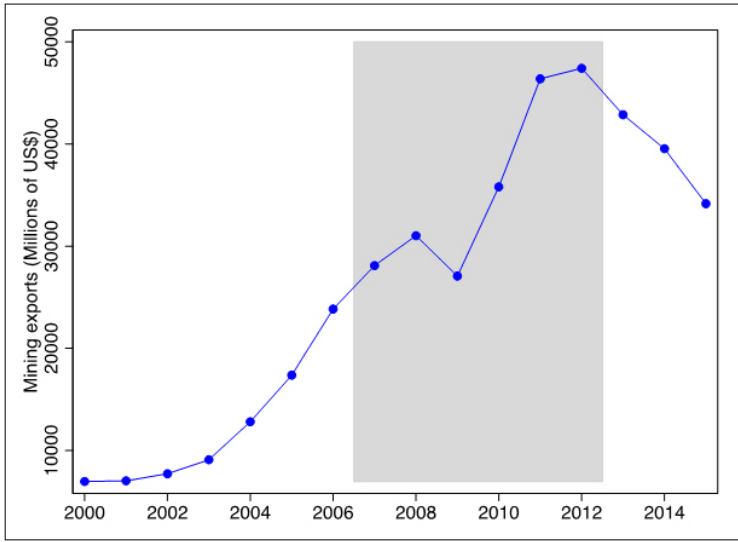

\section{B. Canon transfers among top 8 receiving districts, 2007-2012}

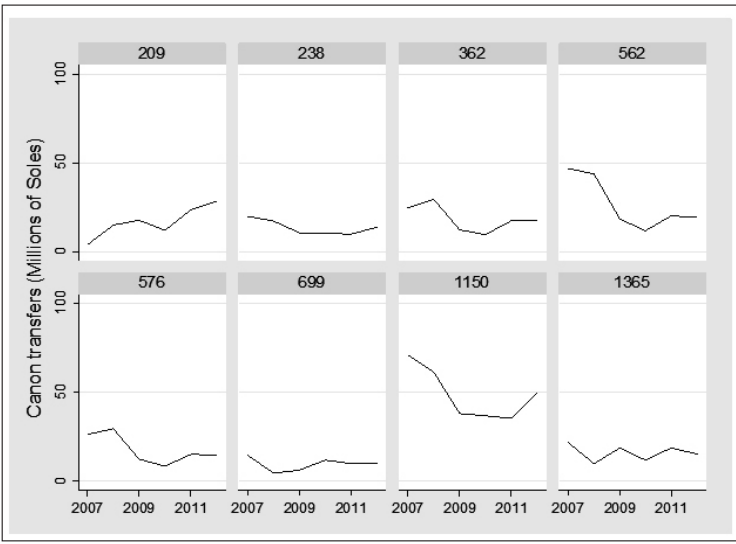

Note: Shaded area (top figure) indicates the period of analysis (2007-2012).

Source: Authors' calculation based on data from Peru's Ministry of Finance. 


\section{Figure A3}

\section{Mining canon transfer stratified randomizations}

\section{A. Kernel density estimate for the coefficient of canon}

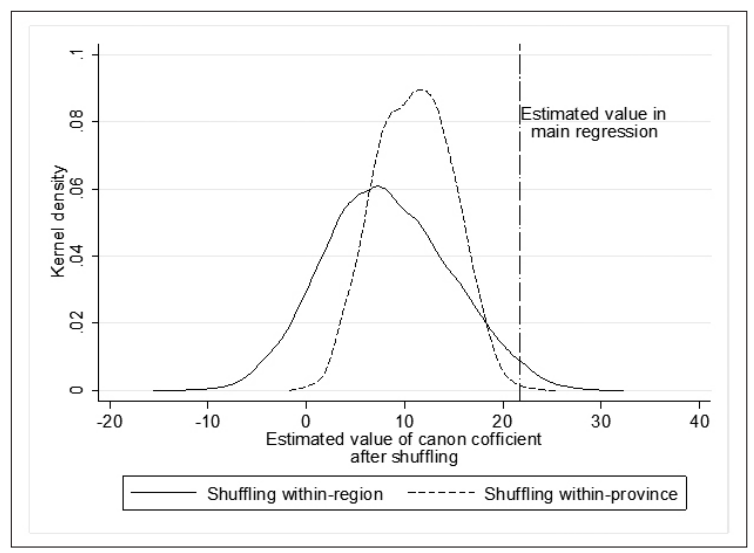

B. Kernel density estimate for the coefficient of canon squared

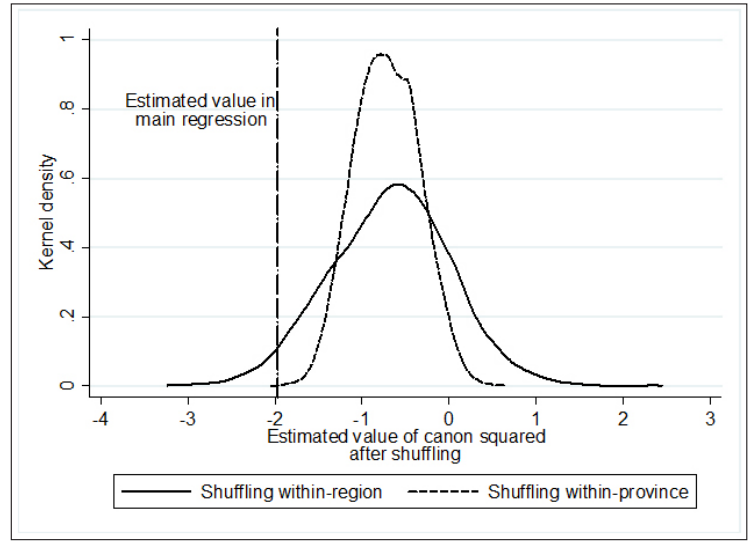

Bandwidth: 0.2

Note: In the corresponding regressions, mining and canon correspond to the value of mining production per-capita and canon per-capita, in thousands of USD at constant prices of 2010. All regressions include fixed effects at the district level. The regressions do not include school characteristics or student characteristics.

Source: Authors' calculations based on data from Peru's Ministries of Education, of Finance, of Energy and Mines, and INEI. 


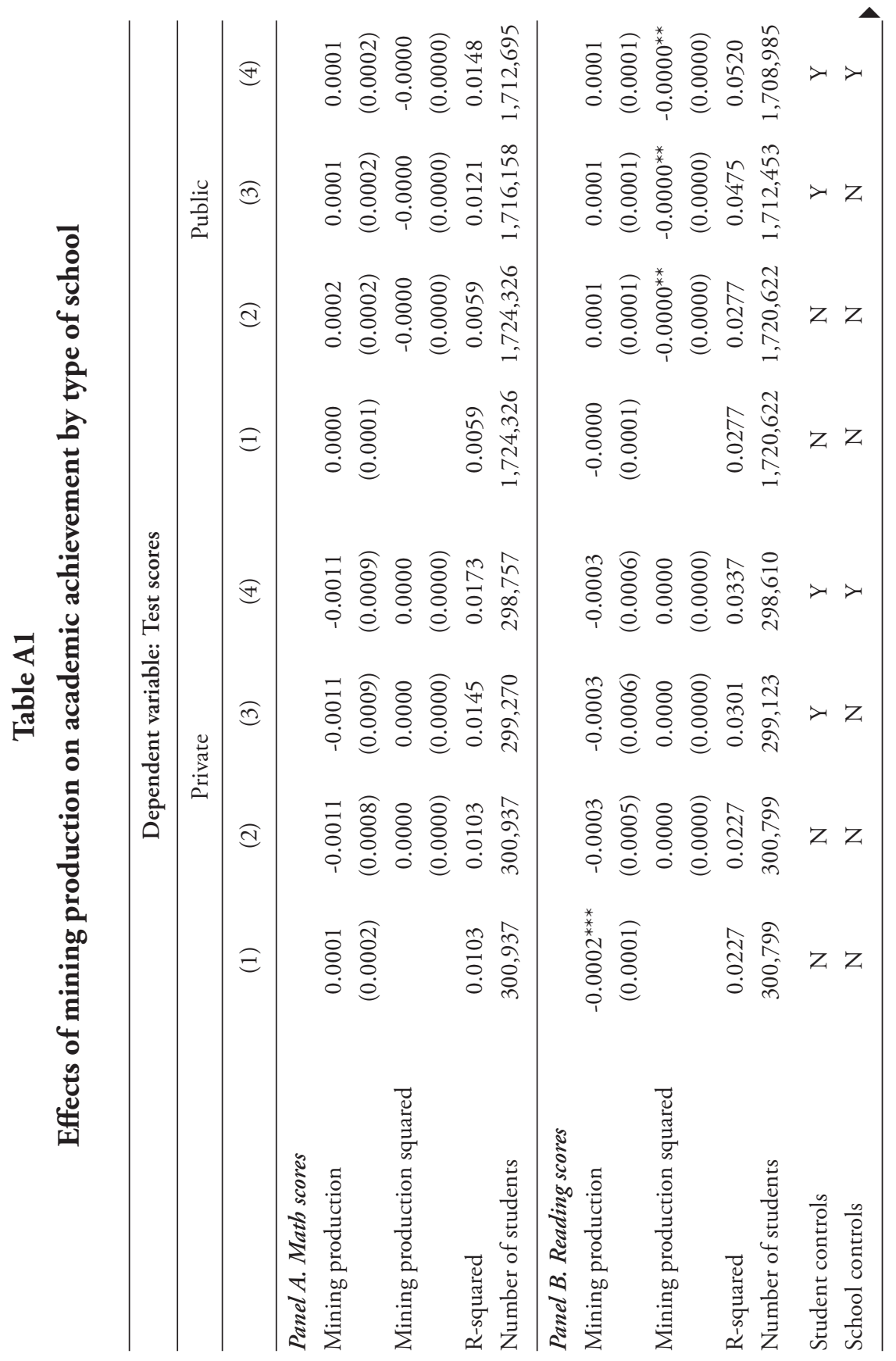




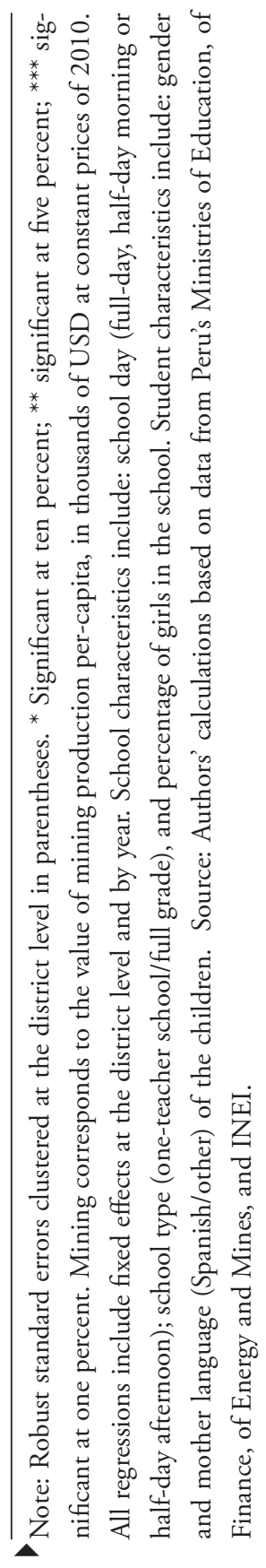




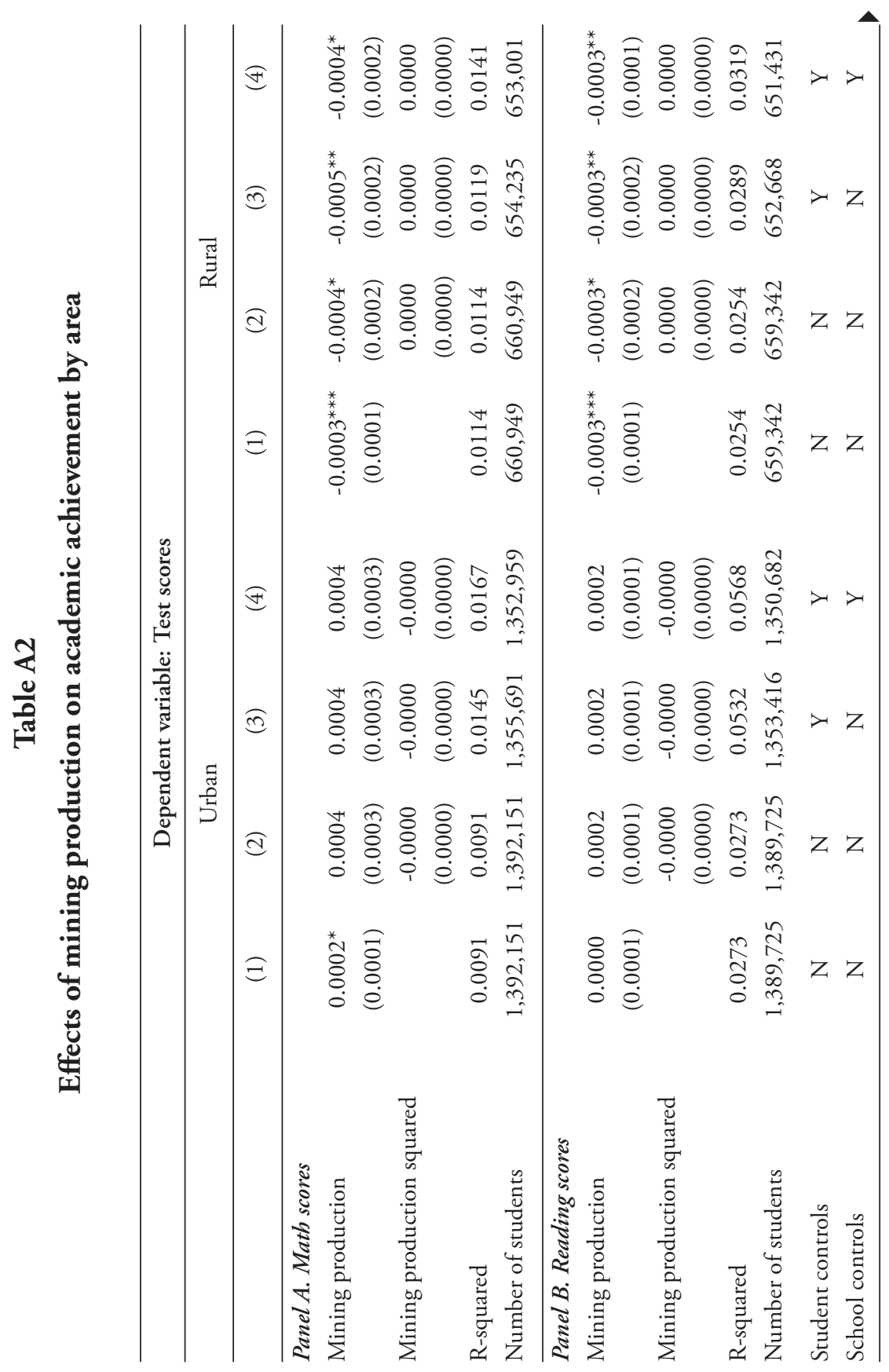




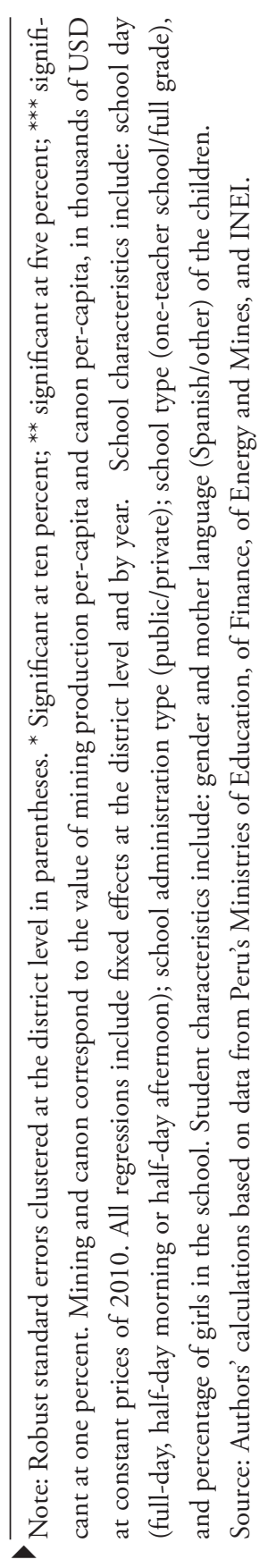


Table A3

Robustness check: Evaluating parametric specification

Dependent variable: Test scores

(1) (2) (3) (4)

(5)

Panel A. Math scores

Canon

6.9139

$21.6714^{* *}$

$21.7054^{* *}$

17.8974

15.8582

(4.6448)

(9.5905) (9.6360)

(14.1336)

(18.9668)

Canon squared

$$
\begin{array}{llll}
-1.9654^{* *} & -1.9679^{* *} & 0.1377 & 2.5463
\end{array}
$$

$\begin{array}{llll}(0.8429) & (0.8453) & (3.7444) & (10.2298)\end{array}$

Mining production

$\begin{array}{lll}-0.0000 & -0.0000 \quad-0.0000\end{array}$

$(0.0001) \quad(0.0001) \quad(0.0001)$

Cubic canon

$-0.1818 \quad-0.7278$

$(0.2622) \quad(1.7987)$

Quartic canon

0.0335

(0.0971)

F-test for quadratic specification

\subsection{7}

[0.0257]

F-test for nested models comparison:

Quadratic versus Cubic model

0.73

[0.3926]

F-test for nested models comparison:

0.59

Quadratic versus Quartic model

[0.5561]

\begin{tabular}{|c|c|c|c|c|c|}
\hline Number of students & 2072339 & 2072339 & 2072339 & 2072339 & 2072339 \\
\hline \multicolumn{6}{|l|}{ Panel B. Reading scores } \\
\hline Canon & $\begin{array}{l}-0.6112 \\
(1.7751)\end{array}$ & $\begin{array}{l}-2.6721 \\
(4.3260)\end{array}$ & $\begin{array}{l}-2.5545 \\
(4.3682)\end{array}$ & $\begin{array}{l}-4.2865 \\
(5.9043)\end{array}$ & $\begin{array}{l}-5.0807 \\
(7.4625)\end{array}$ \\
\hline Canon squared & & $\begin{array}{c}0.2743 \\
(0.3728)\end{array}$ & $\begin{array}{c}0.2656 \\
(0.3743)\end{array}$ & $\begin{array}{c}1.2222 \\
(1.5516)\end{array}$ & $\begin{array}{c}2.1613 \\
(4.2778)\end{array}$ \\
\hline Mining production & & & $\begin{array}{l}-0.0001 \\
(0.0001)\end{array}$ & $\begin{array}{l}-0.0001 \\
(0.0001)\end{array}$ & $\begin{array}{l}-0.0001 \\
(0.0001)\end{array}$ \\
\hline Cubic canon & & & & $\begin{array}{l}-0.0826 \\
(0.1128)\end{array}$ & $\begin{array}{l}-0.2953 \\
(0.7865)\end{array}$ \\
\hline Quartic canon & & & & & $\begin{array}{c}0.0131 \\
(0.0434)\end{array}$ \\
\hline
\end{tabular}


Dependent variable: Test scores
(1)
(2)
(3)
(4)

(5)

F-test for quadratic specification

0.72

[0.4872]

F-test for nested models comparison:

Quadratic versus Cubic model

[0.5167]

F-test for nested models comparison:

Quadratic versus Quartic model

[0.8063]

\begin{tabular}{llllll}
\hline Number of students & 2068271 & 2068271 & 2068271 & 2068271 & 2068271 \\
\hline
\end{tabular}

Note: Robust standard errors clustered at the district level in parentheses. ${ }^{*}$ Significant at ten percent; ${ }^{* *}$ significant at five percent; ${ }^{* * *}$ significant at one percent. Mining and canon correspond to the value of mining production per-capita and canon per-capita, in thousands of USD at constant prices of 2010. All regressions include fixed effects at the district level and by year. School characteristics include: school day (full-day, half-day morning or half-day afternoon); school administration type (public/private), and school type (one-teacher school/ full grade). Student characteristics include: gender and mother language (Spanish/other) of the children. Source: Authors' calculations based on data from Peru's Ministries of Education, of Finance, of Energy and Mines, and INEI. 
Table A4

Robustness check: Non-producing districts

Non-producing districts in producing provinces

Dependent variable: Scores
(1)
(2)
(3)
(4)

Panel A. Math scores

Canon

$\begin{array}{cccc}15.3272^{* *} & 42.9592^{* * *} & 42.9592^{* * *} & 44.0927^{* * *} \\ (7.2185) & (9.2665) & (9.2665) & (9.2499) \\ & -4.0120^{* * *} & -4.0120^{* * *} & -4.1620^{* * *} \\ & (0.8158) & (0.8158) & (0.8099) \\ 0.0062 & 0.0067 & 0.0067 & 0.0204 \\ 407870 & 407870 & 407870 & 400466\end{array}$

Canon squared

R-squared

407870

407870

407870

(1)

Panel B. Reading scores

Canon

$-3.8087$

$-5.3912$

$-5.3912$

$-4.5662$

(2.4266)

(5.6013)

(5.6013)

(5.6375)

Canon squared

0.2281

0.2281

0.0850

(0.4882)

(0.4882)

(0.4810)

R-squared

0.0210

0.0210

0.0210

0.0597

Number of students

407261

407261

407261

399885

Student controls

School controls

$\mathrm{N}$

$\mathrm{N}$

Y

Y

$\mathrm{N}$

$\mathrm{N}$

$\mathrm{N}$

$\mathrm{Y}$

Note: Robust standard errors clustered at the district level in parentheses. ${ }^{*}$ Significant at ten percent; ${ }^{* *}$ significant at five percent; ${ }^{* * *}$ significant at one percent. Canon corresponds to the value of canon per-capita, in thousands of USD at constant prices of 2010. All regressions include fixed effects at the district level and by year. School characteristics include: school day (full-day, half-day morning or half-day afternoon); school administration type (public/private), and school type (one-teacher school/full grade). Student characteristics include: gender and mother language (Spanish/other) of the children. Source: Authors' calculations based on data from Peru's Ministries of Education, of Finance, of Energy and Mines, and INEI. 


\section{Table A5}

\section{Robustness check: Non-producing districts}

Non-producing districts in non-producing provinces

Dependent variable: Scores

(1)

(2)

\section{Panel A. Math scores}

Canon

$\begin{array}{ccc}3.0216 & 11.3721 & 14.4347 \\ (7.0492) & (20.0901) & (20.2367) \\ & -0.9788 & -1.2158 \\ & (1.7309) & (1.7321) \\ 0.0055 & 0.0055 & 0.0163 \\ 840,920 & 840,920 & 817,235\end{array}$

Panel B. Reading scores

Canon

Canon squared

R-squared

(0.5473)

Number of students

0.0242

0.0242

0.0600

Student controls

839,965

839,965

816,281

School controls

$\begin{array}{ll}\mathrm{N} & \mathrm{N} \\ \mathrm{N} & \mathrm{N}\end{array}$

Y

Note: Robust standard errors clustered at the district level in parentheses. * Significant at ten percent; ${ }^{* *}$ significant at five percent; ${ }^{* * *}$ significant at one percent. Canon corresponds to the value of canon per-capita, in thousands of USD at constant prices of 2010. All regressions include fixed effects at the district level and by year. School characteristics include: school day (full-day, half-day morning or half-day afternoon); school administration type (public/private), and school type (one-teacher school/full grade). Student characteristics include: gender and mother language (Spanish/other) of the children. Source: Authors' calculations based on data from Peru's Ministries of Education, of Finance, of Energy and Mines, and INEI. 


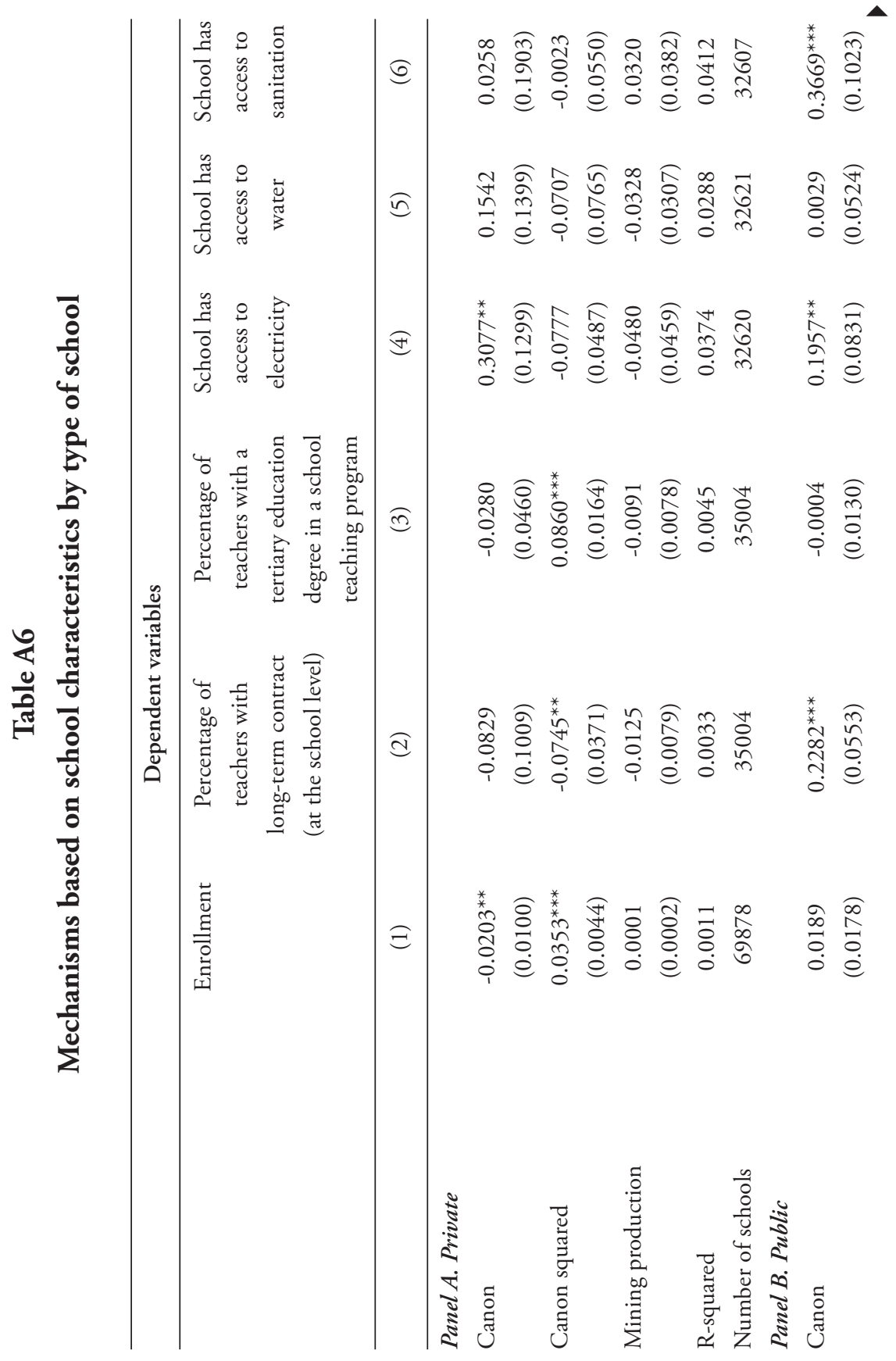




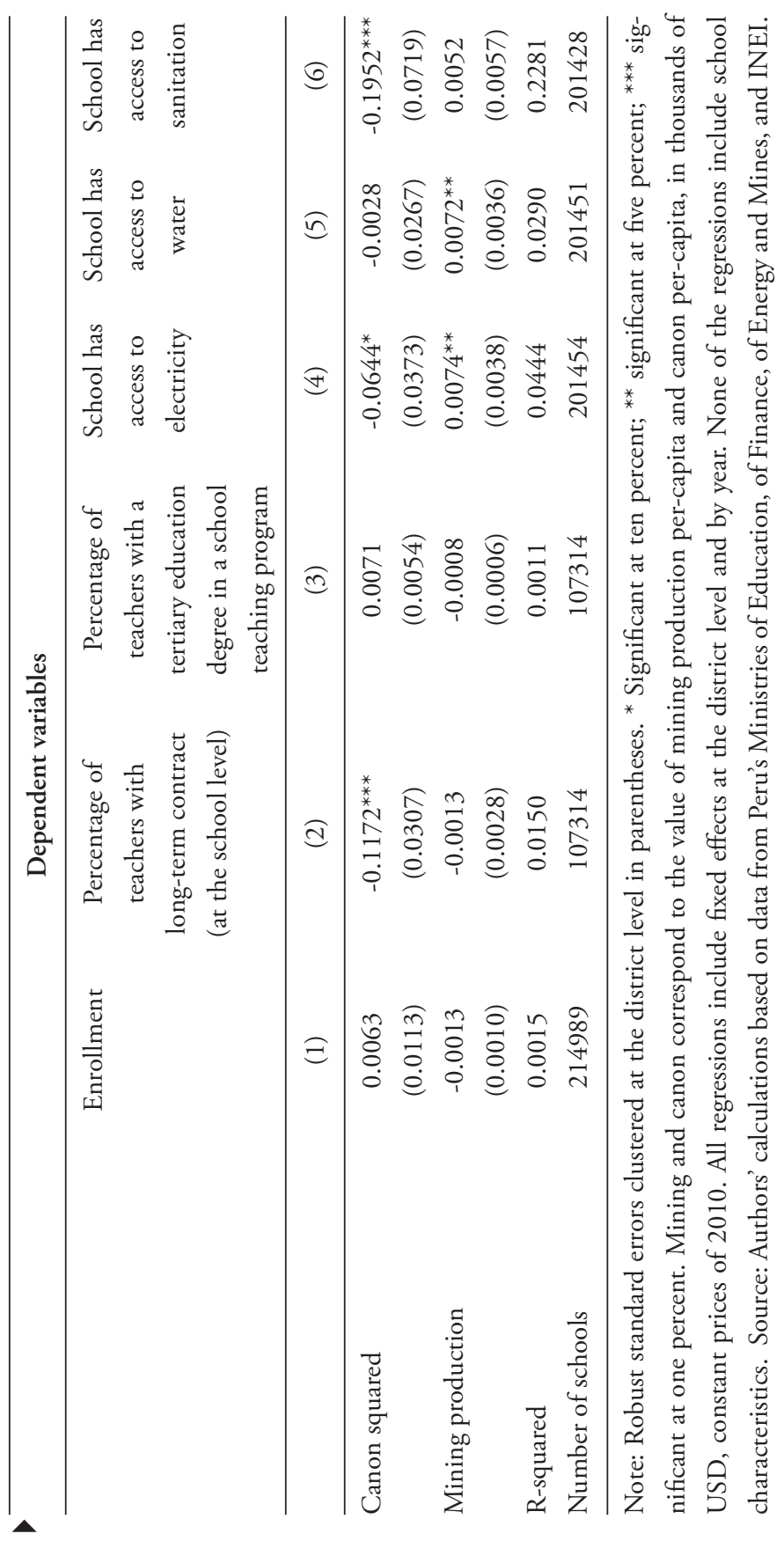




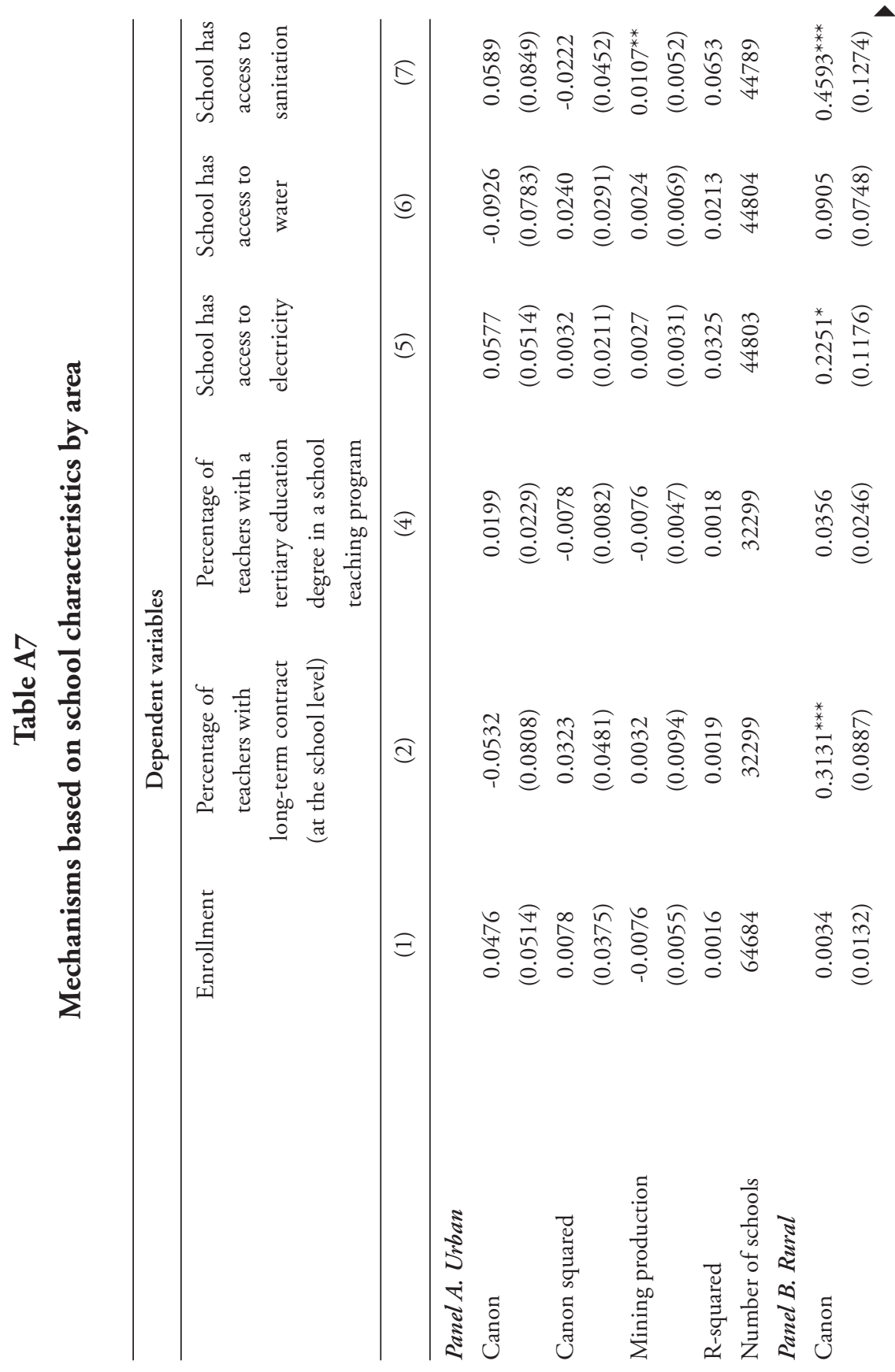




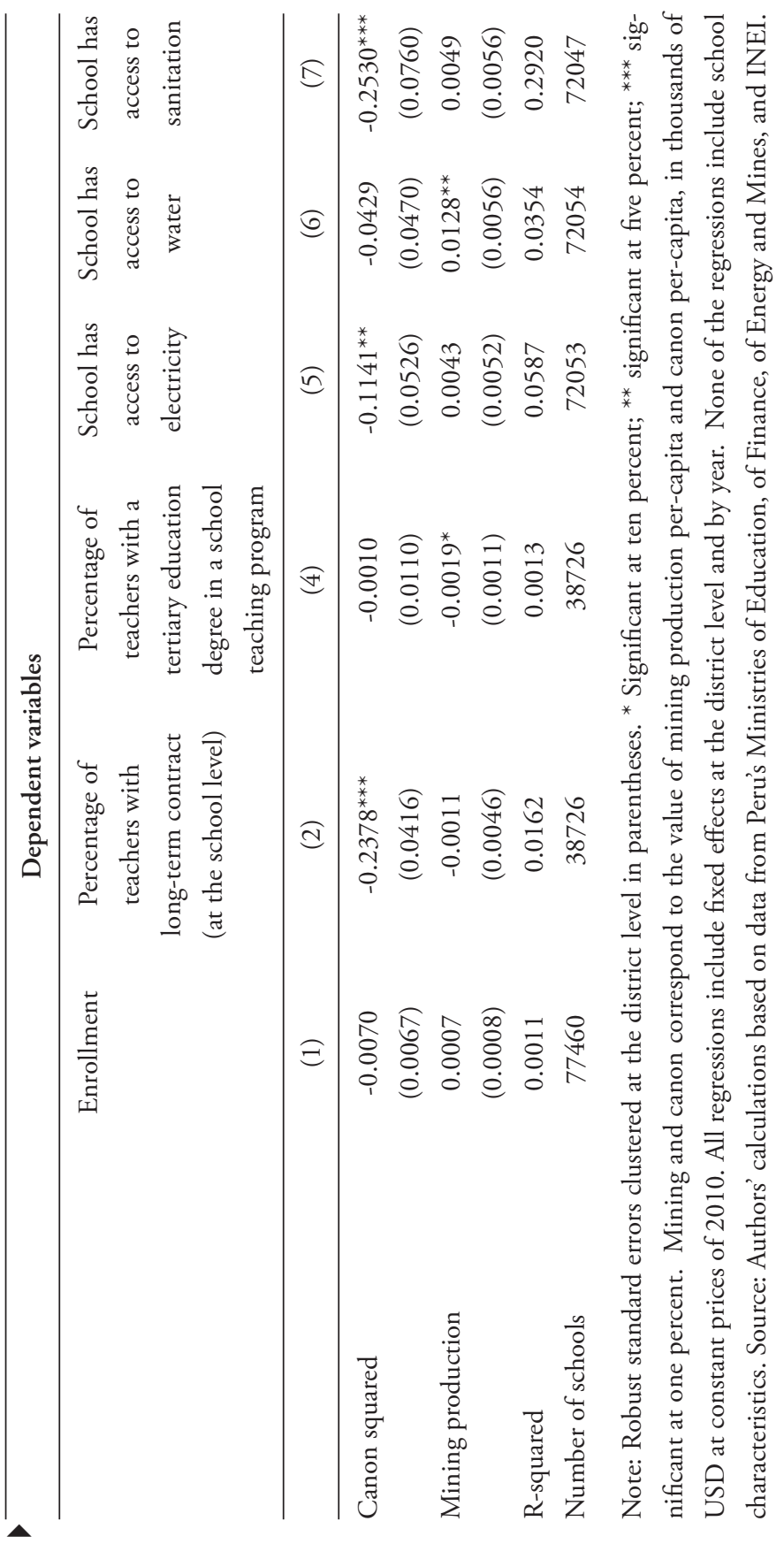




\section{Table A8}

\section{Mechanisms based on economic conditions by area}

\begin{tabular}{|c|c|c|c|c|c|}
\hline \multicolumn{6}{|c|}{ Dependent variables } \\
\hline & $\begin{array}{c}\text { Unemployed } \\
(14-65 \\
\text { years of age })\end{array}$ & $\begin{array}{c}\text { Employed } \\
\text { in the } \\
\text { public sector } \\
\text { (14 - } 65 \\
\text { years of age })\end{array}$ & $\begin{array}{l}\text { Spending on } \\
\text { education } \\
\text { per-student }\end{array}$ & $\begin{array}{c}\text { Monthly } \\
\text { consumption } \\
\text { per-capita }\end{array}$ & $\begin{array}{c}\text { Monthly } \\
\text { income } \\
\text { per-capita }\end{array}$ \\
\hline & (1) & (2) & (3) & (4) & (5) \\
\hline \multicolumn{6}{|l|}{ Panel A. Urban } \\
\hline \multirow[t]{2}{*}{ Canon } & -0.0340 & 0.0189 & 0.0097 & -0.0995 & -0.0771 \\
\hline & $(0.0417)$ & $(0.0770)$ & $(0.1936)$ & $(0.0867)$ & $(0.1104)$ \\
\hline \multirow[t]{2}{*}{ Canon squared } & -0.0011 & -0.0056 & -0.0428 & $0.0440^{*}$ & $0.0716^{* *}$ \\
\hline & $(0.0176)$ & $(0.0207)$ & $(0.0977)$ & $(0.0236)$ & $(0.0331)$ \\
\hline \multirow[t]{2}{*}{ Mining production } & 0.0021 & -0.0030 & -0.0093 & -0.0008 & 0.0040 \\
\hline & $(0.0049)$ & $(0.0030)$ & $(0.0084)$ & $(0.0115)$ & $(0.0085)$ \\
\hline R-squared & 0.0004 & 0.0009 & 0.0256 & 0.0284 & 0.0229 \\
\hline Number of observations & 343629 & 84713 & 49864 & 83190 & 83184 \\
\hline \multicolumn{6}{|l|}{ Panel B. Rural } \\
\hline \multirow[t]{2}{*}{ Canon } & $-0.0677^{*}$ & $0.3150^{* * *}$ & 0.1160 & -0.0805 & 0.0601 \\
\hline & $(0.0371)$ & $(0.0893)$ & $(0.2062)$ & $(0.1044)$ & $(0.1300)$ \\
\hline \multirow[t]{2}{*}{ Canon squared } & $0.0292^{*}$ & $-0.1211^{* *}$ & $-0.1839^{*}$ & -0.0509 & -0.1048 \\
\hline & $(0.0152)$ & $(0.0503)$ & $(0.1040)$ & $(0.0423)$ & $(0.0650)$ \\
\hline \multirow[t]{2}{*}{ Mining production } & 0.0011 & $-0.0100^{* * *}$ & $0.0205^{*}$ & 0.0066 & 0.0015 \\
\hline & $(0.0029)$ & $(0.0037)$ & $(0.0116)$ & $(0.0078)$ & $(0.0050)$ \\
\hline R-squared & 0.0005 & 0.0164 & 0.0579 & 0.0612 & 0.0437 \\
\hline Number of observations & 230581 & 32730 & 28372 & 53665 & 53665 \\
\hline
\end{tabular}

Note: Robust standard errors clustered at the district level in parentheses. ${ }^{*}$ Significant at ten percent; ${ }^{* *}$ significant at five percent; ${ }^{* * *}$ significant at one percent. Mining corresponds to the value of mining production per-capita, in thousands of USD at constant prices of 2010. All regressions include fixed effects at the district level and by year. None of the regressions include school characteristics. Source: Authors' compilations based on ЕNAHO household survey data and data from Peru's Ministry of Finance and Peru's Ministry of Mines and Energy. 


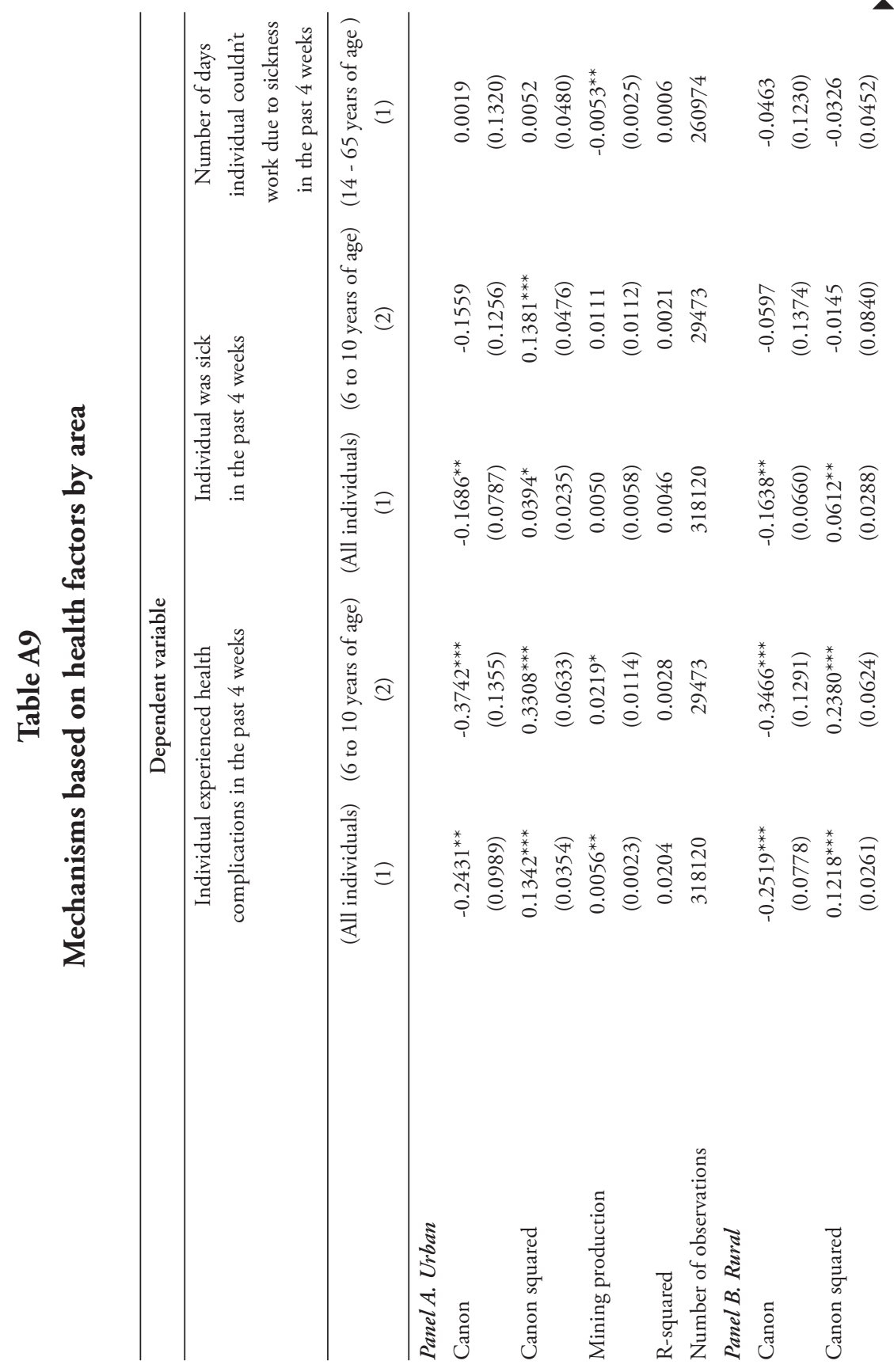




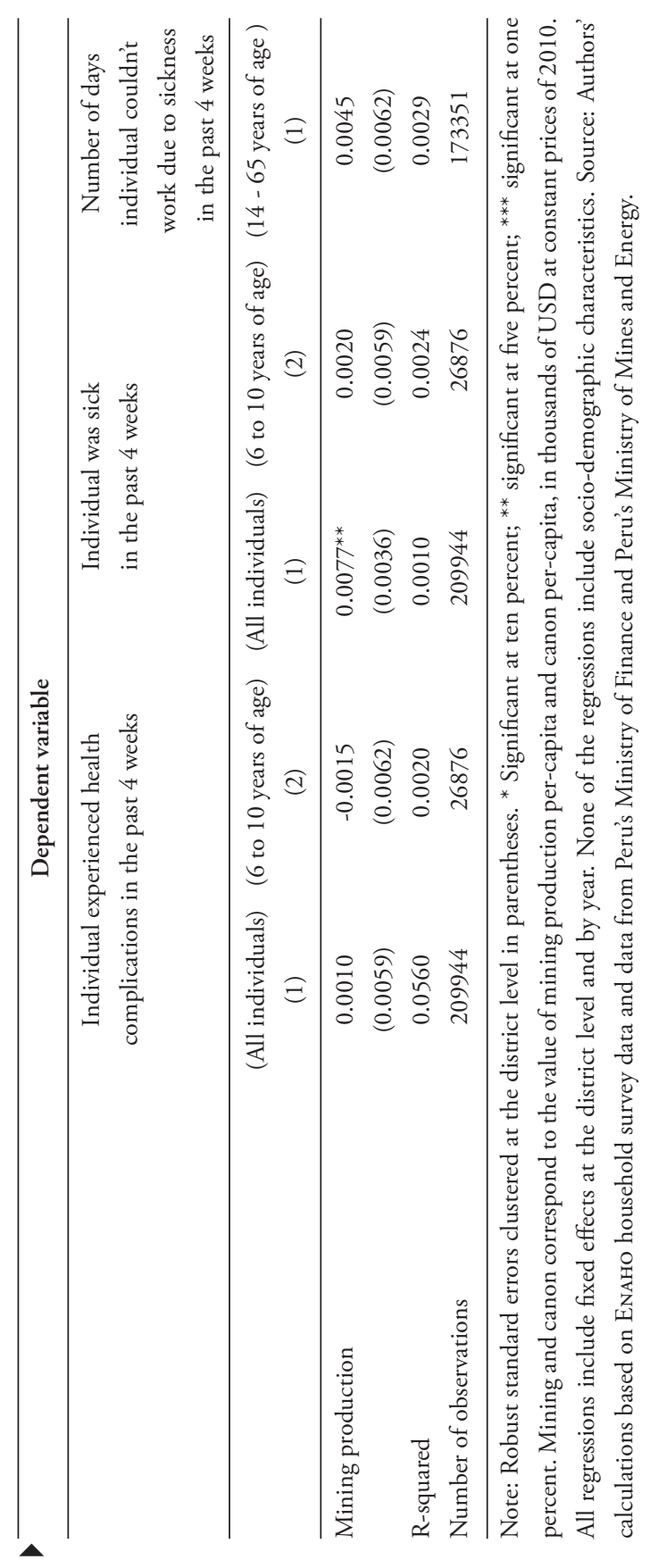



The Value of Redistribution:

Natural Resources and the Formation of

Human Capital under Weak Institutions

se terminó de editar en el mes de agosto del 2017. 